\title{
COVID-19: pathogenesis, advances in treatment and vaccine development and environmental impact-an updated review
}

\author{
Youssef A. Attia ${ }^{1,2,3}$ (D) Mohamed T. El-Saadony ${ }^{4} \cdot$ Ayman A. Swelum $^{5,6}$ (D) Shaza Y.A. Qattan ${ }^{7} \cdot$ Adel D. Al-qurashi $^{1}$ • \\ Khalid A. Asiry ${ }^{1}$ - Manal E. Shafi ${ }^{8}$. Ahmed R. Elbestawy ${ }^{9}$. Ahmed R. Gado ${ }^{9}$. Asmaa F. Khafaga ${ }^{10}$. \\ Elsayed O.S. Hussein ${ }^{5}$. Hani Ba-Awadh ${ }^{5}$. Ruchi Tiwari ${ }^{11} \cdot$ Kuldeep Dhama $^{12}$ - Bakr Alhussaini ${ }^{13} \cdot$ Salem R. Alyileili $^{14}$. \\ Khaled A. El-Tarabily ${ }^{15,16}$. Mohamed E. Abd El-Hack ${ }^{17}$ (D)
}

Received: 26 December 2020 / Accepted: 15 February 2021 / Published online: 18 March 2021

(C) The Author(s), under exclusive licence to Springer-Verlag GmbH Germany, part of Springer Nature 2021

\begin{abstract}
Diseases negatively impact the environment, causing many health risks and the spread of pollution and hazards. A novel coronavirus, severe acute respiratory syndrome coronavirus type 2 (SARS-CoV-2) has led to a recent respiratory syndrome epidemic in humans. In December 2019, the sudden emergence of this new coronavirus and the subsequent severe disease it causes created a serious global health threat and hazards. This is in contrast to the two aforementioned coronaviruses, SARSCoV-2 (in 2002) and middle east respiratory syndrome coronavirus MERS-CoV (in 2012), which were much more easily contained. The World Health Organization (WHO) dubbed this contagious respiratory disease an "epidemic outbreak" in March 2020. More than 80 companies and research institutions worldwide are working together, in cooperation with many governmental agencies, to develop an effective vaccine. To date, six authorized vaccines have been registered. Up till now, no approved drugs and drug scientists are racing from development to clinical trials to find new drugs for COVID-19. Wild animals, such as snakes, bats, and pangolins are the main sources of coronaviruses, as determined by the sequence homology between MERS-CoV and viruses in these animals. Human infection is caused by inhalation of respiratory droplets. To date, the only available treatment protocol for COVID-19 is based on the prevalent clinical signs. This review aims to summarize the current information regarding the origin, evolution, genomic organization, epidemiology, and molecular and cellular characteristics of SARS-CoV-2 as well as the diagnostic and treatment approaches for COVID-19 and its impact on global health, environment, and economy.
\end{abstract}

Keywords Antiviral drugs $\cdot$ Disease prevention $\cdot$ Pathology $\cdot$ SARS-CoV-2 $\cdot$ Therapies $\cdot$ Vaccines

\section{Introduction}

In late December 2019, a disease outbreak caused by a novel coronavirus (2019-nCoV) started in Wuhan, China, and rapidly spread to more than 200 countries (Lai et al. 2020). By the

Responsible Editor: Lotfi Aleya

Youssef A. Attia

yaattia@kau.edu.sa

Ayman A. Swelum

aswelum@ksu.edu.sa

Khaled A. El-Tarabily

ktarabily@uaeu.ac.ae

Extended author information available on the last page of the article 11th of February 2020, the World Health Organization (WHO) announced the official name for the disease that is caused by this new coronavirus, coronavirus disease 2019 (COVID-19). Later, the causative virus was named severe acute respiratory syndrome coronavirus type 2 (SARS-CoV2) by the Coronavirus Study Group (CSG) of the International Committee on Taxonomy of Viruses (ICTV), which is responsible for the official classification of viruses and viral taxonomy (Yu et al. 2020). Subsequently, due to its rapid spread across many countries, this epidemic of SARS-CoV-2 infection was classified as a pandemic by the WHO on March 11, 2020 (Gautret et al. 2020).

The name SARS-CoV-2 covers the evolutionary history of coronavirus that causes severe acute respiratory syndrome (SARS). Similar to other coronaviruses (CoVs), SARS$\mathrm{CoV}-2$ particles are spherical (when imaged at the atomic 
level using cryogenic electron microscopy) and have spike proteins projecting from their surface (Kaniyala Melanthota et al. 2020). These spikes allow the virus to fuse with the host cell membrane after binding to human cells; then, they undergo structural changes (Xu et al. 2020a). Through protein modeling experiments, Zhang et al. (2020a) revealed that SARS-CoV-2 has sufficient affinity for angiotensinconverting enzyme 2 (ACE2), which is found on the surface of human alveolar cells II, to suggest their involvement in the mechanism of viral entry (Xiu et al. 2020).

Coronaviruses are positive-sense single-stranded RNA (ssRNA) enveloped viruses, with a size range $65-125 \mathrm{~nm}$ in diameter (Pal et al. 2020). Coronaviruses belong to the Coronavirinae family, Coronaviridae subfamily, and order Nidovirales (Pooladanda et al. 2020). Numerous large prominent projections are present on the outer surface of the viral envelope, giving the virus a crown-shaped appearance (in Latin, corona means crown) (Li et al. 2020). A previous study conducted by Enjuanes et al. (2006) showed that coronaviruses are classified into four major genera: alpha $(\alpha)$, beta $(\beta)$, gamma $(\gamma)$, and delta $(\delta)$. While alpha $(\alpha)$ and beta $(\beta)$ strains of coronavirus infect mammals, causing mild to severe respiratory and gastrointestinal symptoms, gamma $(\gamma)$ coronavirus strains infect avian species, and delta $(\delta)$ coronavirus strains infect both mammals and avian species. Cui et al. (2019) reported that, so far, seven coronavirus strains have been identified that cause human infections, including four human CoVs (HCoV-NL-63, HCoV-229E, HCoVOC43, and HKU1), SARS-CoV-1, MERS-CoV, and SARS$\mathrm{CoV}-2$. The four human $\mathrm{CoV}$ viruses cause mild respiratory and gastrointestinal infections. Only SARS-CoV-1, MERS$\mathrm{CoV}$, and SARS-CoV-2 have been reported to cause severe lower respiratory tract infections that can lead to pneumonia (Khan et al. 2020).

The spread of the novel coronavirus, at different time intervals, posed serious health threats to both humans and animals, and has led to severe economic losses and considerable environmental changes (Dhama et al. 2020a; Swelum et al. 2020). In late December 2019, in Wuhan City, Hubei province, China, several people suffering from severe pneumonia with unknown etiology were reported (Qun 2020). Enjuanes et al. (2006) previously carried out a genomic sequencing study on an unknown etiological pathogen isolated from these patients with pneumonia, which revealed a virus with 79.5\% identity to SARS-CoV. Chinese scientists first named this virus novel Coronavirus-2019 (nCoV-2019). From December 31, 2019, to February 8, 2021, the WHO reported $106,008,943$ million confirmed cases of COVID-19 and $2,316,389$ million deaths due to this disease, for a mortality rate of $2.19 \%$.

An epidemic outbreak of SARS-CoV beginning in Guangdong province, China, affected people in 32 countries and resulted in more than 8,422 cases and 919 deaths (a case fatality rate of 11\%) (WHO 2003). In 2012, the emergence and spread of MERS-CoV from Saudi Arabia to 27 nations resulted in 2,449 cases and 858 deaths (a case fatality rate of $34.4 \%$ ) (Singal et al. 2020). Similarly, Jung and Saif (2015) reported that, in 2013, the emergence and spread of porcine epidemic diarrhea coronavirus (PEDV) in the USA killed more than $10 \%$ of the piglet population under 1-year old. This virus has a high fatality rate, almost $100 \%$, and seriously impacted pig farming in the USA.

\section{Structure of SARS-CoV-2}

Coronaviruses are round in shape, with an average diameter of $80-120 \mathrm{~nm}$, and possess numerous club-shaped (17-20 nm) glycoprotein spike-like projections on the surface of their viral envelope. The virus particle contains four major structural proteins, glycoprotein spikes (S), an envelope protein (E), matrix protein $(\mathrm{M})$, and nucleocapsid $(\mathrm{N})$ protein. Nonstructural proteins (nsps), such as 3-chymotrypsin-like protease, papain-like protease, and RNA-dependent RNA polymerase, are also encoded by the open reading frame (ORF) region.

Chan et al. (2020), Wu et al. (2020), and Yang et al. (2020a) demonstrated that the glycoprotein spikes mediate viral attachment to host cell receptors, depending upon the receptor-binding domain (RBD). Depending on their attachment, the $\mathrm{S}$ protein is cleaved into two subunits, namely, the $\mathrm{N}$-terminal S1 and C-terminal S2 subunits, by a host protease. The S1 subunit contains a signal peptide and receptor-binding domain (RBD). The S2 subunit contains a conserved fusion peptide (FP), heptad repeat (HR) peptides, a transmembrane domain (TM), and a cytoplasmic domain. The S1 subunit of SARS-CoV-2 showed a 70\% identity to the S1 subunits of Beta coronaviruses (SARS-CoV) isolated from humans and bats (Jin et al. 2020).

Xia et al. (2020) found that the S1 subunit, which contains the RBD, mediates viral attachment to ACE2, which is the key receptor used to infect human cells. Xia et al. (2020) demonstrated that the $\mathrm{S} 2$ subunit plays an important role in mediating viral fusion and entry into the host cell; heptad repeats 1 and 2 (HR1, HR2) can interact with six helical bundles, thereby bringing the viral and cellular membranes close enough to promote fusion. The ACE2-binding affinity of the RBD in the $\mathrm{S} 1$ subunit of SARS-CoV-2 is 10-20-fold higher than that of SARS-CoV (Xia et al. 2020), leading to the higher infectivity and transmissibility of SARS-CoV-2 (Walls et al. 2020). The M glycoproteins are preglycosylated polypeptides, with a size range of $25-30 \mathrm{kDa}$ (221-262 amino acids), that give shape to the viral envelope (Armstrong et al. 1984).

The E protein is a small polypeptide, $8.4-12 \mathrm{kDa}$ in length (76-109 amino acids), that is an integral membrane protein (Sohag et al. 2020). Godet et al. (1992) reported that E protein facilitates assembly of the virus particle. The helical $\mathrm{N}$ protein, 
43-50 kDa in size, encloses the long unsegmented negativestrand RNA genome (Chang et al. 2006). N protein is the most abundant and is a highly immunogenic phosphorous protein of SARS-CoV-2 making it an ideal marker for diagnostic assays. A fifth structural protein called hemagglutinin (HE) projects from the surface of the viral envelope and enhances S-protein-mediated cell entry through the mucosa (Fehr and Perlman 2015). Recently, Chen et al. (2020a) described the SARS-CoV-2 virion as a 50-200-nm diameter, positivesense, single-stranded RNA betacoronavirus. Additionally, $\mathrm{Li}$ and De Clercq (2020) reported high similarity with SARS-CoV and MERS-CoV.

\section{Genome structure of SARS-CoV-2}

The genomes of coronaviruses range from 29.9 to $30 \mathrm{~kb}$ and consist of a long, nonsegmented, single-stranded, positive-sense RNA (++ssRNA) with a $5^{\prime}$ cap and a $3^{\prime}$ polyadenylated (poly-A) tail, and encode 9,860 amino acids (WHO 2003; Chang et al. 2006; Gorbalenya et al. 2020). The 5'- and 3'-UTRs of SARS-CoV-2 are 265 and 358 nucleotides long, respectively. The UTR sequences at the $5^{\prime}$ and $3^{\prime}$ termini of SARS-CoV-2 are $>83.6 \%$ identical to those of other betacoronaviruses (Chan et al. 2020; Kumar et al. 2020).

Recent studies conducted by Chan et al. (2020) and $\mathrm{Wu}$ et al. (2020) showed that the SARS-CoV-2 genome contains 14-16 ORFs (ORfla/b, ORF3a, ORF6, ORF7, ORF8, and ORF9) encoding 27 proteins. ORF1a/b, located at the $5^{\prime}$ terminus, accounts for two-thirds of the length of the genome and encodes 15-16 nsps (nsp1-10 and nsp12-16). Devi et al. (2020) reported that frameshift signals located between ORF1a and ORF1b lead to the production of two polypeptides, ppla and pplab, that are processed either by viral-encoded chymotrypsin-like protease (3CLpro) or main protease (Mpro) into $16 \mathrm{nsps}$ that aid in viral replication. The other ORFs account for the remaining one-third of the viral genome near the 3'-terminus, and they encode four structural proteins $(\mathrm{S}, \mathrm{E}, \mathrm{M}$, and $\mathrm{N}$ ), and $5-8$ accessory proteins (ORF3a, ORF3b, P6, ORF6, ORF7a/b, ORF8b, and ORF9b and ORF1).

According to Pachetti et al. (2020), the RNA-dependent RNA polymerase (RdRps), also named nsp12, is a key component of the virus replication/transcription machinery that shares high homology with nsp12 from SARS-CoV, suggesting conserved function. Xia et al. (2020) revealed that the viral RNA genome is used as a template for direct translation of the poly-protein $1 \mathrm{a} / 1 \mathrm{ab}$ (pp1a/pp1ab), which encodes the nsps that form the replication-transcription complex.

Genomic organization and structural features of SARS$\mathrm{CoV}-2$ are represented in Fig. 1.

\section{Origins of coronaviruses}

Coronaviruses causing human infections originate from wild animals, including bats, pangolins, and camels and are transmitted to humans through intermediate hosts, such as civet cats, camels, and pangolins (Dhama et al. 2020b; Konda et al. 2020; Yuan et al. 2020). Cauchemez et al. (2013), Zhou et al. (2020), and $\mathrm{Wu}$ et al. (2020) reported that SARS-CoV-1 and MERS-CoV originated from bats and were transmitted to humans through intimate contact with other hosts, including civet cats and camels.

The origin of SARS-CoV-2 is still unclear and has been debated among researchers while cross-species jumping has been implicated in its origin, and this virus has been reported from cats, dogs, tigers, lions, and minks (Dhama et al. 2020b; Tiwari et al. 2020). According to Andersen et al. (2020), there are two theories on the origin of SARS-CoV-2.

First theory: a few scientists believe that SARS-CoV-2 emerged through laboratory manipulations of SARS-CoVlike coronaviruses. The RBD of SARS-CoV-2 is optimized for binding ACE-2, which is distinct from other coronaviruses (Astuti and Ysrafil 2020; Zhang et al. 2020a). However, the genetic data on SARS-CoV-2 does not show any evidence of a laboratory origin.

Second theory: SARS-CoV-2 is thought to have originated from the wet seafood market in Wuhan, China (Wu et al. 2020). Wild animals sold in the market may be a source of infection. Genomic sequencing of a virus from Rhinolophus affinis bat (bat-RaTG13) showed $96 \%$ identity with the genomic sequence of SARS-CoV-2 (Chibber et al. 2020). Similarly, genome sequencing of a pangolin coronavirus obtained from illegally imported Malayan pangolins in Guangdong province, China, had a sequence identical to that of SARS-CoV-2. However, Zhang et al. (2020b) showed that the genomic sequence of bat-RaTG13 is more similar to that of SARS-CoV-2 than to the pangolin coronavirus. Most researchers agree that bats or pangolins are the primary reservoirs of coronaviruses, but the transmission route of SARS$\mathrm{CoV}-2$ to humans from this primary reservoir is still under study (Dhama et al. 2020b; Hafez and Attia 2020).

\section{Pathogenesis of SARS-CoV-2 and organs affected}

Coronaviruses infect the lower respiratory tract as well as other organs using ACE2 as a key cell receptor for infection (Dhama et al. 2020c; Ni et al. 2020). Human infection occurs following the inhalation of respiratory droplets produced by symptomatic and asymptomatic infected patients (Cauchemez et al. 2013; Astuti and Ysrafil 2020). Moreover, Li et al. (2003) and Shang et al. (2020) reported that SARS-CoV-2, SARS, and HCoV-NL63 utilized ACE2 as a key receptor, while MERS-CoV uses dipeptidyl peptidase 4 (DPP4) as a key receptor for host cell attachment and infection. 


\section{Genomic organization of}

SARS-COV-2

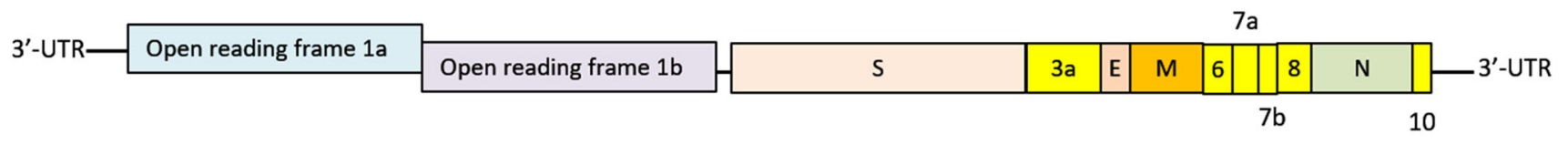

\section{Structure of SARS- CoV-2}

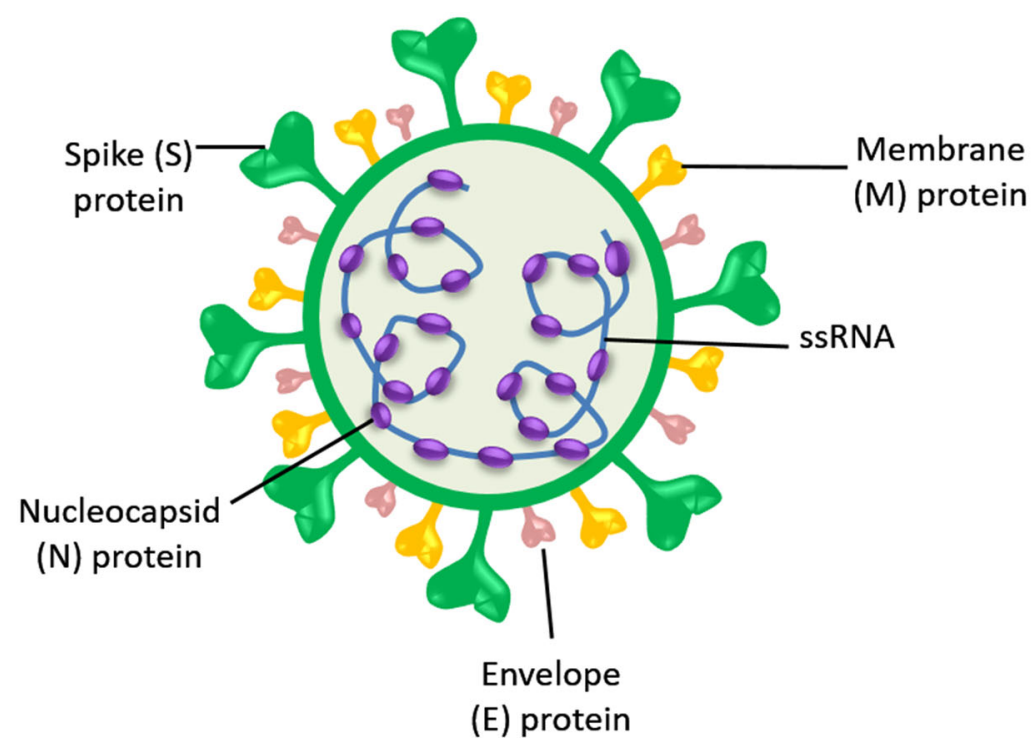

Fig. 1 Schematic representation of the genomic organization and structural features of SARS-CoV-2 (Xia et al. 2020)

Li et al. (2019), Skariyachan et al. (2019), and Xia et al. (2020) reported that coronavirus entry also depends on cellular proteases, including human airway trypsin-like protease (HAT), cathepsins, and transmembrane protease serine 2 (TMPRSS2), which cleave the viral spike protein leading to further structural changes that enhance infection. Mousavizadeh and Ghasemi (2020) and Shang et al. (2020) reported that entry and attachment of the S protein of SARS$\mathrm{CoV}-2$ to the host cell receptor (ACE2) result in viral fusion with the host cell membrane and release of the viral RNA into the host cell cytoplasm. The sites of SARS-CoV-2 infection include body organs with ACE2 receptors, such as the lower respiratory tract, kidney, heart, liver, and intestinal tract (Chiocchetti et al. 2020; Dhama et al. 2020c). Moreover, Mousavizadeh and Ghasemi (2020) stated that cytoplasmic viral replication and transcription involved a coordinated process of RNA synthesis, mediated by viral replicase, which is a huge protein complex encoded by the $20-\mathrm{kb}$ replicase gene. The viral structural proteins (S, E, M, and N) and nonstructural proteins (viral nucleic acid RNA, and other enzymes) are processed in the endoplasmic reticulum and Golgi apparatus of the host cell. These proteins assemble at the host cell membrane to form mature viral progeny, which are released through the secretory vesicles via exocytosis (Li et al. 2019) and can infect surrounding cells. Some of these viral progeny may enter the bloodstream, causing primary viremia.
A recent study by Dhama et al. (2020c) demonstrated that dissemination and lodgment of the virus in different body organs (i.e., the heart, kidney, intestine, and liver) containing ACE2 receptors trigger strong host immune responses, causing uncontrolled production of pro-inflammatory cytokines, such as IFN $\alpha$, INF- $\gamma$, IL-1 $\beta$, IL-6, IL-12, IL18, IL-3, TNF- $\alpha$, TGF- $\beta$, IL-2, IL-10, MCP1, IL-1RA, GCSF, IP-10, MCAP-1, and MIP- $1 \alpha$, and chemokines, such as CCL2, CCL3, CXCL8, CXCL9, and CXCL10, into the blood. Prompetchara et al. (2020) added that this uncontrolled production of chemokines and cytokines causes pulmonary/ alveolar tissue damage, leading to acute respiratory distress syndrome (ARDS) and after ends with the death of the patient.

Immunopathogenesis of SARS-CoV-2 is illustrated in Fig. 2.

\section{Incubation period}

The incubation period for SARS-CoV is $2-7$ days and may extend up to 10 days and is 2-14 days for MERS-CoV (Leung et al. 2004).

\section{Symptoms of SARS-CoV-2 viral infection}

COVID-19 can induce relatively nonspecific symptoms, and some infected people may be entirely asymptomatic. 


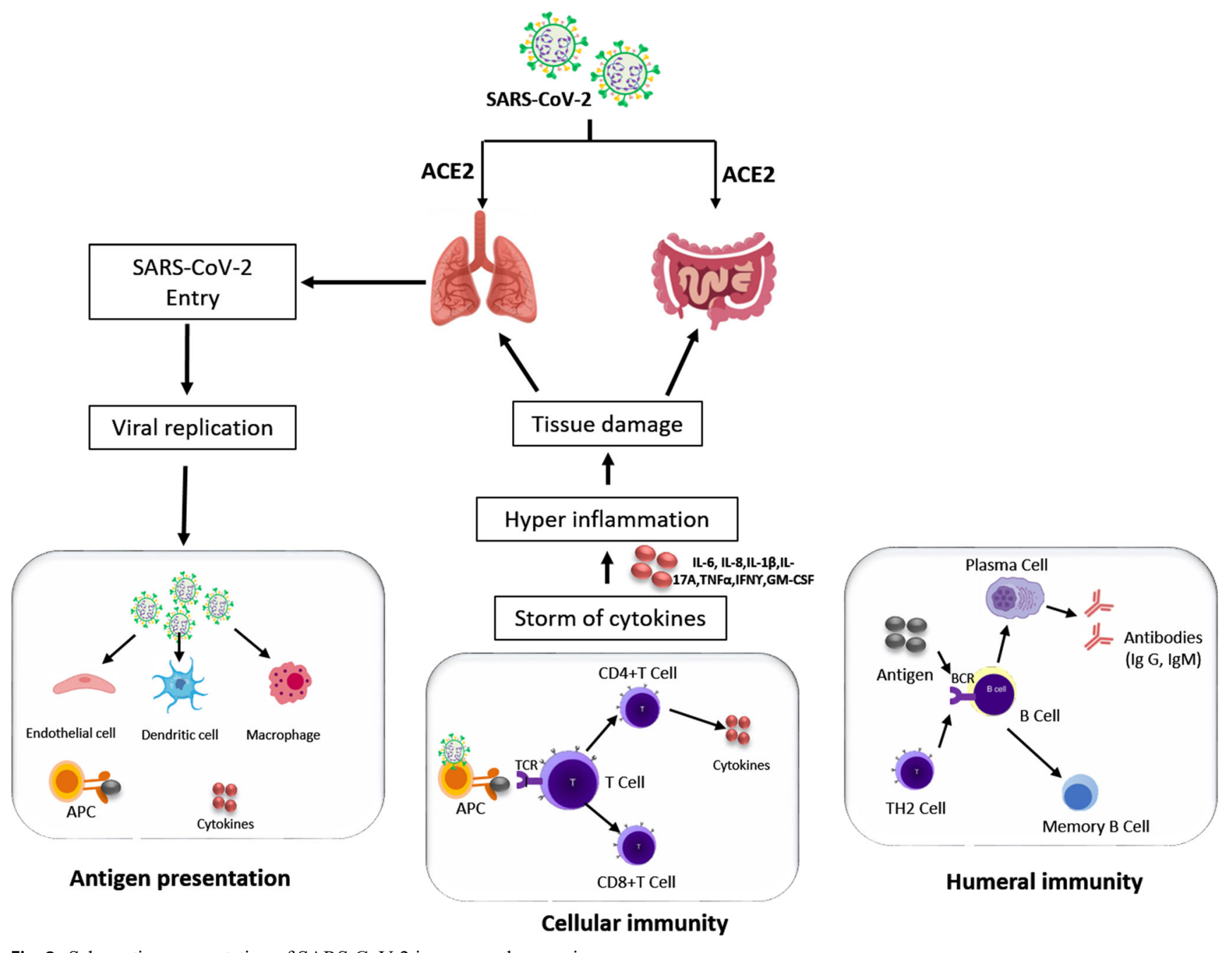

Fig. 2 Schematic representation of SARS-CoV-2 immunopathogenesis

However, fever is the most common symptom (88\%), followed by dry cough (68\%). Fatigue, sore throat, phlegm or respiratory sputum production, shortness of breath, loss of the sense of smell, muscular and articular pain, headache, chills, hemoptysis, and diarrhea are other symptoms, as well as vomiting and cyanosis, which are less common, and the disease signs are more severe in immunocompromised patients (Dhama et al. 2020c; Di Wu et al. 2020; Fung et al. 2020).

Children appear to experience a milder form of COVID-19 than do adults (Dong et al. 2020a; Garazzino et al. 2020; Lee et al. 2020a). Even in immunocompromised children due to different underlying conditions, the course of illness is benign and mild symptoms or asymptomatic are present (El Dannan et al. 2020).

\section{Changes in host cell immunity caused by SARS-CoV-2}

The role of herd immunity or both cell-mediated and humoral immune responses during SARS-CoV-2 infections is not yet precisely illustrated. However, SARS-CoV-2 might induce a T-cell-mediated protective immune response.

Recent studies by Shi et al. (2019), Andersen et al. (2020), and Diao et al. (2020) revealed that, upon entry and replication of SARS-CoV-2, uncontrolled stimulation of CD4+ and $\mathrm{CD} 8+$ cells can result in the production of large amounts of pro-inflammatory cytokines (TNF- $\alpha$, IL- $1 \beta$, IL-6, GCSF, IP10 , and MCAP-1) and macrophage inflammatory proteins (IFN $\alpha$, INF- $\gamma$, IL-1 $\beta$, IL-6, IL-12, IL18, IL-3, TNF- $\alpha$, TGF- $\beta$, IL-2, IL-10, MCP1, and IL-1RA) in the patient's blood, in addition to chemokines (CCL2, CCL3, CXCL8, CXCL9, and CXCL10), which might play a significant role in the progression of COVID-19. It is crucial to identify the functions of these cytokines, and the different viral mechanisms that cause tissue damage and contribute to multiple organ failure in patients with severe COVID-19 (Dhama et al. 2020c; Keam et al. 2020).

Diao et al. (2020) and Qin et al. (2020) reported that the sustained, substantial reduction in peripheral lymphocyte counts, mainly CD4+, CD8+, NK, and B cells, in COVID- 
19 patients, suggest possible suppression of the cellular immune response with disease progression. This progression is associated with a high risk of developing secondary bacterial infections. This reduction in peripheral lymphocyte counts is known as lymphopenia; however, the underlying mechanism is unknown. Samaddar et al. (2020) reported that the humoral immune response also plays an important role in controlling COVID-19. IgM antibodies start to appear within 7-14 days after viral infection and then gradually decrease with the progression of the disease. $\operatorname{IgG}$ antibodies start to appear in the patient's blood after 14 days and remain for an extended time period. The sustainable existence of $\operatorname{IgG}$ antibodies against the viral S-protein as a specific neutralizing antibody response plays an important role in determining disease outcomes.

\section{Reproduction number and transmission rate}

Fraser et al. (2009) defined the virus reproduction rate (R0) as the expected number of cases directly generated by one case in a population where all individuals are susceptible to infection. Recently, Read et al. (2020) demonstrated that viruses with an R0 value $>1$ cause serious epidemics or pandemics. In contrast, an $\mathrm{R} 0$ value $<1$ guarantees that the transmission will fade. SARS-CoV-2 has R0 values greater than one, typically in the range of 3.3-5.5, which is slightly higher than that of SARS-CoV (R0 2-5) (Chen et al. 2020b; Liu et al. 2020a). The R0 of MERS-CoV was 0.69 (95\% CI 0.42-0.80), which is relatively low, but still poses a risk of causing a pandemic. The R0 of influenza virus is 1.1-2.3.

\section{Clinical picture}

According to the Center for Disease Control and Prevention (CDC), the clinical spectrum of COVID-19 varies from asymptomatic to symptomatic and is classified as mild, moderate, and severe based on the clinical spectrum (Pan et al. 2020). Patients with SARS-CoV-2 infection (COVID-19) typically present with high-grade fever, a dry cough, malaise, and dyspnea as major symptoms, and with headache, nasal congestion, runny nose, sore throat, myalgia, vomiting, and diarrhea as minor symptoms (Dhama et al. 2020c; Hoang et al. 2020).

Huang et al. (2020a) and Yang et al. (2020b) showed that the occurrence and frequency of the clinical manifestations of COVID-19 varied in different regions. Patients with severe COVID-19 develop pneumonia (Vabret et al. 2020), and death occurs due to acute respiratory distress syndrome (ARDS), septicemia, and multiple organ failure (Huang et al. 2020b).

\section{Epidemiology}

An early epidemiological investigation on the SARS-CoV-2 outbreak in mainland China suggested that the infection spread from the local Huanan seafood market in Wuhan, Hubei province, China. A cluster of pneumonia cases was reported in the last week of December 2019. Since then, the virus has spread rapidly, infecting millions of people. This drew global health attention to SARS-CoV-2.

\section{Patients}

On December 8, 2020, the WHO reported 66,729,375 confirmed cases and more than 1,535,982 deaths due to COVID19 , for a global mortality rate of $2.30 \%$ (WHO 2020). Recent studies from the CDC (2020) and Raoult et al. (2020) demonstrated that COVID-19 cases varied among different nations from different continents. American and European countries were more affected by COVID-19 than Asian and African countries. The highest mortality rates due to COVID-19 were reported in people with distinct chronic diseases, comorbidities, and weak immune systems (Arumugam et al. 2020).

\section{Geographical distribution}

In late December 2019, a new coronavirus, SARS-CoV-2, emerged in Wuhan City province in mainland China. By mid-January 2020, an epidemic outbreak of SARS-CoV-2 had spread to other cities of China, infecting thousands of people (Hafez and Attia 2020). By the third week of February 2020, there was a sudden increase in COVID-19 cases in South Korea and Italy, which verified the global spread of the epidemic (Zhang et al. 2020b).

The virus has spread to 215 countries across the world (Chiocchetti et al. 2020). There is no clear evidence as to why the pathogenicity and infectivity of SARS-CoV-2 varied in different countries, but the variation may be associated with a combination of factors, including difference in national strategies adopted to restrict people's movement, isolation and quarantine procedures, genetic differences, and population immunity (Kolifarhood et al. 2020; Pachetti et al. 2020). Generally, the American and European countries were more severely affected than Asian and African countries which may be attributed to many factors as older population, weak public support, and favorable cold and humid climate (WHO 2020). In 2002-2003, SARS-CoV-1 virus emerged in Guangdong, China, and spread to 29 countries, including Canada, Hong Kong, Chinese Taipei, Singapore, and Vietnam, infecting about 8,098 people and resulting in 774 deaths (Ding et al. 2003).

\section{Age distribution and sex ratio}

According to the CDC (2020) and Verity et al. (2020), hospitalization due to COVID-19 increased with age, with a $1 \%$ chance for individuals $20-29$ years, $4 \%$ for individuals 50 59 years, and $18 \%$ for those older than 80 years. The $30-79$ - 
year age group was found to be more vulnerable to SARSCoV-2 infection.

Males are more susceptible to SARS-CoV-2 infection than females (Vellingiri et al. 2020). Raoult et al. (2020) revealed that the male to female ratio for SARS-CoV-2 infection was 0.99:1 in Wuhan and 1.041 in China. Onder et al. (2020) reported that the highest mortality rate due to SARS-CoV-2 infection was in populations $70-80$ years of age.

\section{Deaths, case fatality rates, and mortality}

American (USA and Brazil), India, Russian Federation, and European (UK, France, Spain, and Italy) countries reported the highest fatalities. China reported 4,440 deaths, which is the highest death rate among Asian countries. The highest mortality rate, $14.8 \%$, was reported in patients aged $\geq 80$ years.

Recently, the CDC (2020) and Raoult et al. (2020) reported a $2.8 \%$ fatality rate in males, compared with $1.7 \%$ in females. Epidemiological analysis of new corona pneumonia cases by the CDC (2020) in Mainland China reported higher fatality rates in people with distinct underlying preconditions including $10.5 \%$ for cardiovascular disease, $7.3 \%$ for diabetes, $6.3 \%$ for chronic respiratory diseases, $6 \%$ for hypertension, and $5.6 \%$ for cancer.

In the USA, the CDC reported that $80 \%$ of the deaths associated with COVID-19 were among adults older than 65 years. The fatality rate due to SARS-CoV-2 infection was lower than that for MERS-CoV (34\%) and SARS-CoV (9.6\%), but the number of confirmed cases of COVID-19 is very high and is constantly increasing, which raises a red flag from an epidemiological point of view.

\section{Epidemiological curve}

From December 2019 to the October 6, 2020, SARS-CoV-2 infections increased across the globe, with various epicenters. In an earlier outbreak, Wuhan City was the epicenter, which then shifted to South Korea, Italy, Spain, and the USA. Countries such as China, Italy, Saudi Arabia, and South Korea were able to control the spread of SARS-CoV-2. Currently, countries in America and Europe are more severely affected, with the highest case numbers and death rates (WHO 2020).

\section{SARS-CoV-2 diagnosis}

The CDC recommends the collection of upper respiratory tract specimens (nasal, nasopharyngeal, or oropharyngeal swab) and lower respiratory samples, such as expectorated productive cough and broncho-alveolar lavages, from patients who are intubated. However, collection of these clinical specimens requires direct patient contact, which possesses a high risk of transmission to the healthcare workers.
Many diagnostic tools have been developed to detect the presence of SARS-CoV-2 to differentiate the diagnosis of this viral disease from common cold infections (Afzal 2020; Cheng et al. 2020; Karthik et al. 2020; Kubina and Dziedzic 2020).

Among these tools is (1) real-time reverse transcription polymerase chain reaction (rRT-PCR). Ai et al. (2020) reported that respiratory samples such as nasopharyngeal swabs and oropharyngeal sputum or swabs could be used in this test to detect the presence of viral RNA. The test takes $3 \mathrm{~h}$ to 2 days, with an average time of $7 \mathrm{~h}$, to obtain results; (2) enzymelinked immunosorbent assay (ELISA), which is a serological assay that can be used to detect the presence of recent viral infections, yields results within 2 days (Chhikara et al. 2020), and 3) computed tomography (CT), which is a helpful tool for COVID-19 diagnosis (Salehi et al. 2020). Typical features of CT in patients with COVID-19 include bilateral multilobar ground glass opacities, with peripheral, asymmetric, and/or posterior distribution. Lee et al. (2020b) added that subpleural dominance, crazy paving, and consolidation might develop as the disease evolves.

Diagnosis methods of SARS-CoV-2 are illustrated in Fig. 3.

\section{Laboratory findings}

\section{Blood and biochemical tests}

Recently, Fan et al. (2020) reported that hematological examination of COVID-19 patients showed lymphopenia, with a decrease in CD4+ and CD8+ cells, eosinopenia, and an increase in the erythrocyte sedimentation rate (ESR). Similarly, Mardani et al. (2020) reported that biochemical analysis of patient serum showed increases in serum aspartate transaminase (AST), alanine aminotransferase (ALT), lactate dehydrogenase (LDH), bilirubin, and prolactin as well as elevated levels of inflammatory markers such as C-reactive protein (CRP) and ferritin.

\section{Molecular and serological tests}

Recently, the CDC (2020) recommended using a qRT-PCR assay to detect and quantitatively analyze viral nucleic acids from clinical specimens. This assay can produce a report within 4-6 h. It is a sensitive method that is widely used in laboratories worldwide.

Serological diagnostic tests, such as ELISA and rapid diagnostic tests (RDT), are also used to detect anti-SARS-CoV2 antibodies and antigens in patient blood samples (Carter et al. 2020). ELISA can be used to detect the $\mathrm{N}$ and $\mathrm{S}$ antigens of SARS-CoV-2. It is based on sandwich ELISA and allows rapid quantification of the $\mathrm{N}$ and $\mathrm{S}$ antigens. RDTs are used to detect $\operatorname{IgM}$ and $\operatorname{IgG}$ antibodies against SARS-CoV-2 in 


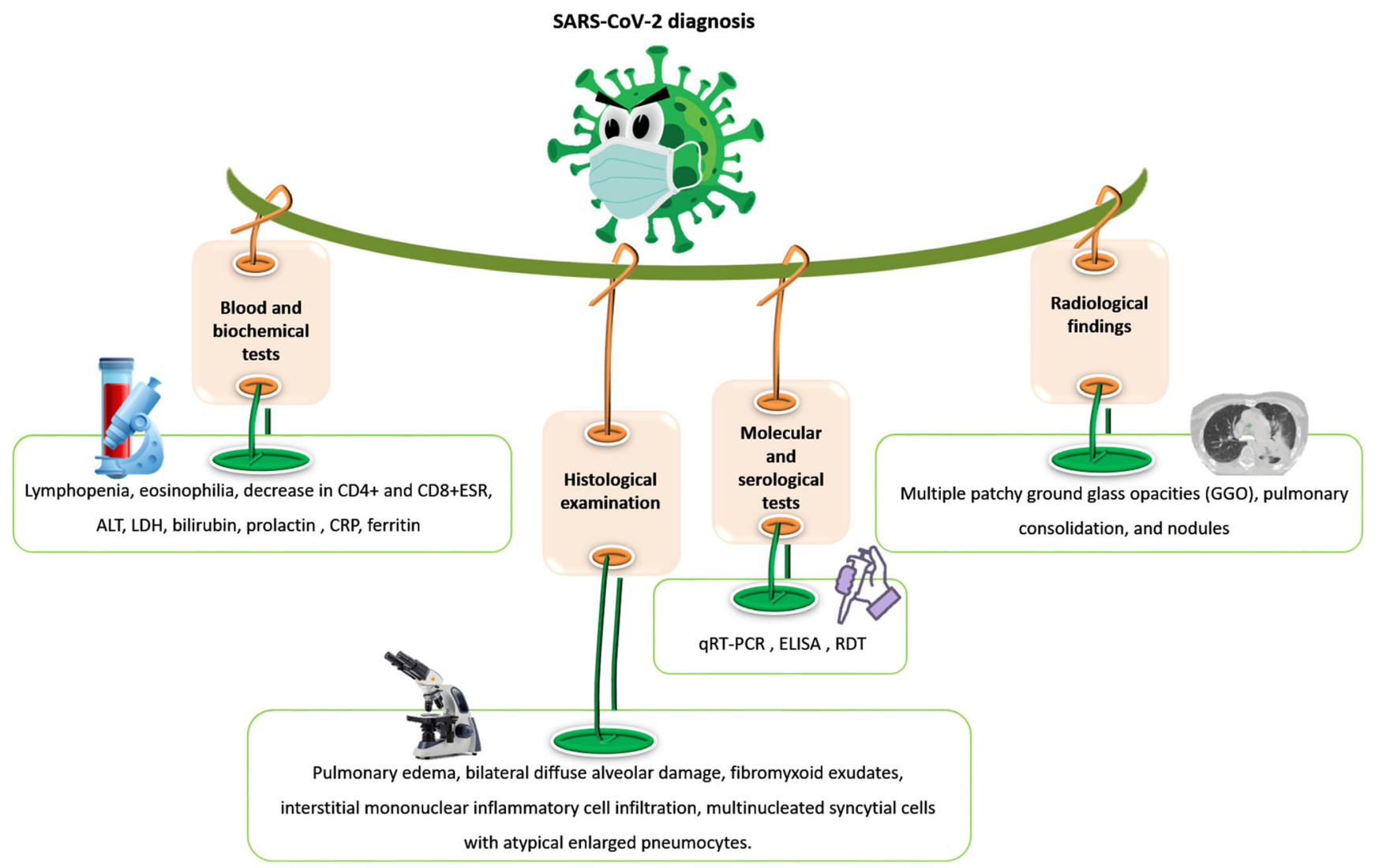

Fig. 3 Diagnosis of SARS-CoV-2

patient serum. The tests are a rapid method that can produce a report within 10-15 min and require a limited instrument.

However, its diagnostic use for detecting acute SARSCoV-2 infection may be limited. The SARS-CoV-2 RDT kit has a sensitivity of $89 \%$ and $\sim 91 \%$ specificity (Li et al. 2019). Currently, the WHO and CDC do not recommend using RDT kits for the diagnosis of SARS-CoV-2 infection. A recent study conducted by Broughton et al. (2020) reported a clustered regularly interspaced short palindromic repeats (CRISPR)/Cas12a-based assay for the detection of SARSCoV-2 from patient samples within 30-40 min. It involves reverse transcription-loop-mediated isothermal amplification (Rt-LAMP) to pre-amplify the viral or control RNA. Then, Cas12a is used for the transcleavage assay. The accuracy of the near-real-time deforestation detection system (DETER) is comparable to that of RT-qPCR and does not require expensive laboratory instrumentation.

It uses similar sample collection procedures and RNA extraction methods as those for RT-qPCR. A CRISPR-based specific high sensitivity enzymatic reporter unlocking technique (SHERLOCK) has also been used for the detection of SARS-CoV-2. It can detect the SARS-CoV-2 target sequence in a concentration range of 20-200 aM (10-100 copies per microliter) (Kang et al. 2020). This test was applied to purify patient RNA samples used for qRT-PCR and yielded results using a dipstick in less than $1 \mathrm{~h}$, without an expensive instrument. The SHERLOCK technique is more accurate and takes less time than RT-qPCR (Joung et al. 2020).

\section{Histological examination}

Histopathological hematoxylin and eosin (H\&E) staining of lung biopsy tissues from patients with COVID-19 showed pulmonary edema, with bilateral diffuse alveolar damage, fibromyxoid exudates, and interstitial mononuclear inflammatory cell infiltration, dominated by lymphocytes, in both lungs (Kang et al. 2020; Zhang et al. 2020b).

Moreover, Tian et al. (2020) reported the desquamation of pneumocytes with hyaline membrane formation, indicating ARDS in COVID-19 patients. Multinucleated syncytial cells with atypical enlarged pneumocytes, nuclei, and prominent nucleoli, along with the presence of amphophilic cytoplasmic and nuclear granules, suggest the presence of intracytoplasmic and intranuclear viral inclusion bodies. The pathological characteristics of COVID-19 are similar to those reported in SARS-CoV and MERS-CoV infections (Kang et al. 2020; Omolo et al. 2020).

\section{Radiological findings}

In the early stages of COVID-19, a CT scan of the chest often show multiple patchy ground glass opacities (GGO) in the 
periphery of the lungs, along with interstitial changes (Shi et al. 2020; Xu et al. 2020b; Zhang et al. 2020c). However, Rodrigues et al. (2020) reported that a CT of progressing disease showed infiltration of both lungs and multiple bilateral diffuse patches, with GGOs, pulmonary consolidation, and nodules.

Other abnormalities were noted, including opacities of different shapes, with a rounded morphology, with a "reverse halo" sign, a "crazy-paving" pattern, or intralesional cavitation. A previous study by Müller et al. (2003) reported that the radiological findings of COVID-19 were similar to those described in earlier coronavirus outbreaks, such as SARS-CoV and MERS-CoV. Other uncommon radiological imaging findings involve pneumothorax, cavitation, and lymphadenopathy.

\section{Challenges in the control of SARS-CoV-2 infections}

A pandemic outbreak of SARS-CoV-2 poses a serious threat and challenges for reducing the spread of COVID-19 (Hafez and Attia 2020; Malik et al. 2020). The lack of antiviral drugs, vaccines, healthcare setups with proper ventilation, and appropriate diagnostic tools; shortages of medical supplies and protective instruments; and limited skilled healthcare workers and manpower in various nations has created serious challenges in controlling COVID-19, mainly:

1. Strict implementation of infectious disease control measures within hospitals and communities is crucial to protect all healthcare workers and people in a community.

2. Epidemiological experts should conduct training and provide important guidelines for the management and control of COVID-19-infected patients during hospitalization.

3. Most SARS-CoV-2-infected patients should not receive therapy, and treatment of patients without current or future medical needs should be stopped entirely.

4. Trust between people and institutions and between the local population and the government should be maintained. The local communities should adhere to medical advice and respect temporary restrictive measures.

5. Antagonisms between the different countries and their federal governments and local governments should be immediately stopped. Antagonism and a lack of trust during this crucial period will affect scientific collaboration and the control of SARS-CoV-2. Hence, different countries should share their experiences and have distinct scientific activities regarding vaccine and drug development for the treatment of COVID-19 patients.

\section{Vaccine development}

A study conducted by Barrett et al. (2009) defined vaccination as a biological procedure that provides active acquired immunity against a particular infectious disease. Bardiya and Bae (2005) reported that vaccination, as a medical process, is considered the most effective prophylactic method for preventing infectious diseases. According to Plotkin (2005), there are seven main vaccine types: (1) live attenuated, (2) inactivated, (3) subunit (Liljeqvist and Ståhl 1999) or recombinant protein (Cox 2012), (4) polysaccharide, (5) toxoid, (6) RNA/mRNA (Kreiter et al. 2011), and (7) DNA vaccines (Liu 2003). All vaccination mechanisms depend on stimulating the immune response to recognize a threat, destroy it, form target foreign agent-specific immune memory, and then supply the body with efficient prophylaxis against the infection (Florindo et al. 2020).

There are nearly 174 vaccine candidates under trials in preclinical phase, based on varying vaccine platforms, including DNA, RNA, S protein, and/or protein subunits, while 63 vaccine candidates are under clinical evaluation as of January 29, 2021 (Thanh et al. 2020; Yatoo et al. 2020; WHO 2021). By January 2021, eight COVID-19 vaccines become authorized for use after passing phase III. Two vaccines are based on mRNA technology, where the RNA instructs the cells to produce SARS-CoV-2 spike proteins to trigger the immune response as Moderna, USA (stored at $-30{ }^{\circ} \mathrm{C}$ ), managed by Moderna in collaboration with the National Institute of Allergy and Infectious Diseases (NIAID) (Moderna 2020) and Pfizer-BioNTech (stored at $-70{ }^{\circ} \mathrm{C}$ ) (Gudadappanavar and Benni 2020).

Four vector vaccines (adenoviral vectored) in which a harmless virus is engineered to contain the spike gene of SARS-CoV-2 protein manufactured by Oxford-AstraZeneca, England-Sweden (refrigerated at $2-8{ }^{\circ} \mathrm{C}$ ); Janssen infectious diseases and vaccines_-Johnson \& Johnson, USA (refrigerated at $2-8{ }^{\circ} \mathrm{C}$ ); Serum Institute of India (refrigerated at $2-8^{\circ} \mathrm{C}$ ); and Gamaleya, Russia (freeze storage at $-20^{\circ} \mathrm{C}$ ). Also, two inactivated SARS-CoV-2 virus vaccine in which the virus rendered inert through a chemical process that preserves the virus structure, refrigerated at $2-8{ }^{\circ} \mathrm{C}$ (Sinopharm and Sinovac, Beijing, China) (WHO 2021). All the authorized vaccines recommended dosage is 2 doses with 3-4 weeks apart.

The number and progression of COVID-19 vaccine candidates are illustrated in Fig. 4.

\section{Coronavirus vaccine}

The SARS-CoV-2 pandemic has created a serious health problem across the globe. Full control of this virus is almost impossible until an effective vaccine is developed. In general, SARS-CoV-2 infection results in the appearance of virusneutralizing antibodies against glycoprotein $\mathrm{S}$ and RBD. Therefore, many researchers are focusing their investigation on the $\mathrm{S}$ protein or RBD as vaccine targets. 


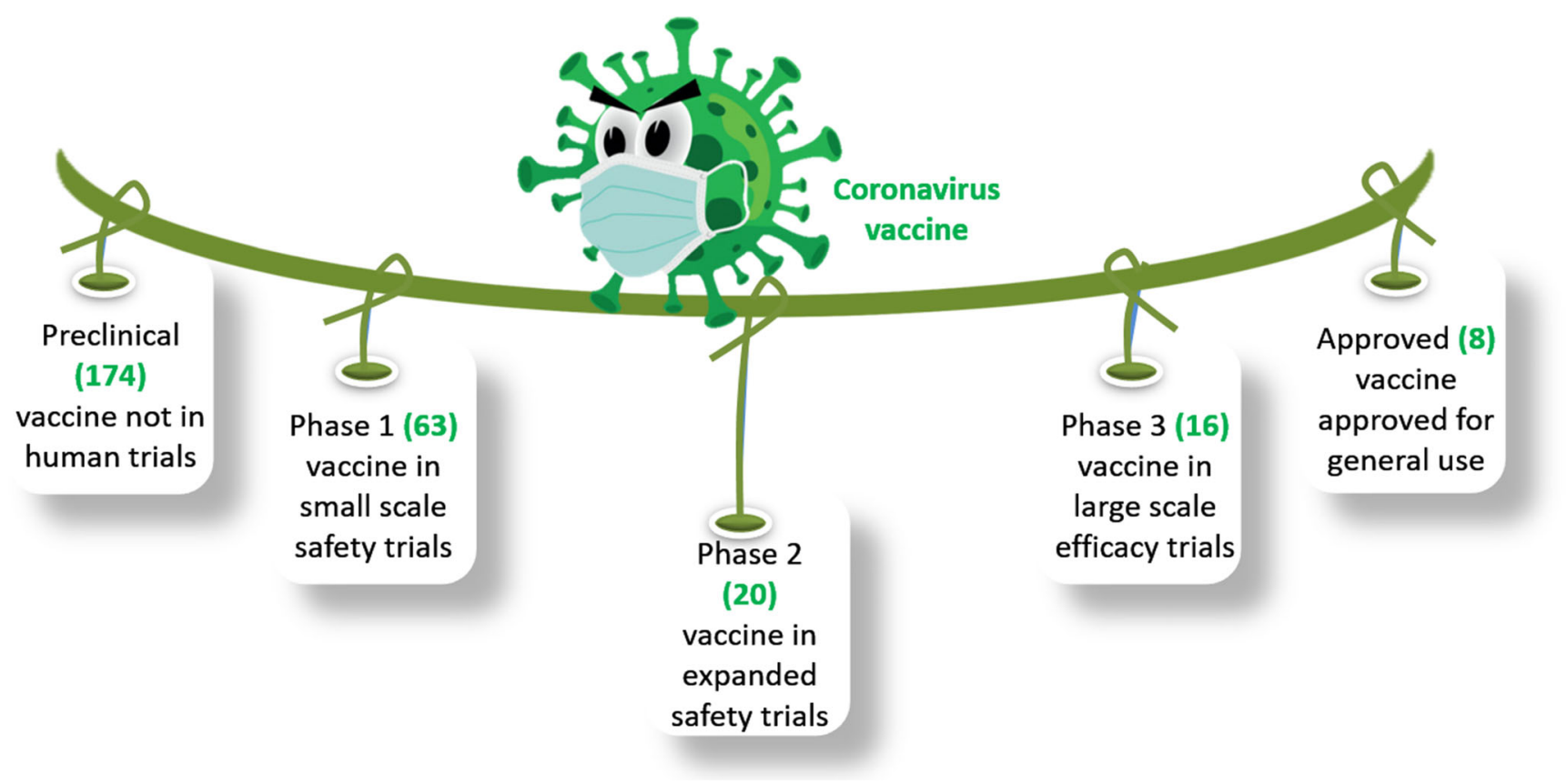

Fig. 4 Number and progression of COVID-19 vaccine candidates

About 78 companies worldwide have begun to develop a vaccine. Thanh et al. (2020) reported that various platforms, including nucleic acid (DNA and RNA) vaccines, virus-based subunit vaccines, mRNA vaccines, live attenuated, and inactivated killed virus vaccines, are being investigated. The most advanced vaccines, which have recently moved into clinical trials, include mRNA-1273 from Moderna, Ad5$\mathrm{nCoV}$ from CanSino Biologicals, INO-4800 from Inovio, LV-SMENP-DC, and pathogen-specific aAPC from Shenzhen Genoimmune Medical Institute. Recently, China's CanSino Biologics and the Institute of Biotechnology of the Academy of Military Medical Sciences used five recombinant adenovirus vector types that have completed phase III trials.

Moderna Therapeutics and the US National Institute of Allergy and Infectious Diseases developed a lipid nanoparticle dispersion containing messenger RNA (mRNA) for its vaccine (mRNA-1273). It began a phase I clinical trial in March 2020 and successfully completed phase III trials. This vaccine encourages the formation of antibodies through the injection of mRNA containing the genetic code for the spike protein found on the virus surface (Pooladanda et al. 2020). Sinopharm and Sinovac Biotech used an inactivated SARS-CoV-2 virus, which completed the three phases. Inactivated SARS-CoV-2 is easy to prepare compared with other vaccines.

All vaccines under development are currently in trials, and it may take 1-2 years or more to bring them to market (Yatoo et al. 2020).

\section{Treatment and management of COVID-19}

Currently, there are no commercially available antiviral drugs or vaccines against SARS-CoV-2. Treatment of patients with
COVID-19 is directed towards boosting immunity (Alagawany et al. 2020; Attia et al. 2020; Jayawardena et al. 2020; Schijns and Lavelle 2020), relieving the symptoms and managing severely ill patients through supportive therapy, including artificial oxygen therapy and hemodynamic support (Hafez and Attia 2020). However, scientists are pursuing ways to slow the spread of the virus and find effective treatments for the SARS-CoV-2 infection (COVID-19) (Dhama et al. 2020a; Rabaan et al. 2020; Vellingiri et al. 2020).

Several existing antiviral medications that have been developed previously and/or used as treatments for several diseases, including SARS, MERS ( $\mathrm{Li}$ and De Clercq 2020), hepatitis B virus (HBV), hepatitis C virus (HCV), influenza virus (Zumla et al. 2016), malaria, and HIV/AIDS, are being researched as possible COVID-19 treatments and are jumping into clinical trials after only a few in silico studies (Li and De Clercq 2020). More recently, dexamethasone has been suggested to be a lifesaving drug for treating critically ill COVID-19 patients (Ledford 2020; Patel et al. 2020).

\section{Use of antiviral, antimalarial, and rheumatoid drugs}

At present, there is no high-level evidence that favors the use of a single antiviral drug for the treatment of patients with suspected or confirmed COVID-19. Thus, several drugs, including chloroquine, arbidol, remdesivir, and favipiravir, are currently undergoing clinical studies to test their efficacy and safety in the treatment of COVID-19 (Dhama et al. 2020a; Rabaan et al. 2020; Vellingiri et al. 2020). 
Different antiviral drugs which can be used for the treatment and management of COVID-19 are illustrated in Table 1.

\section{Chloroquine and hydroxychloroquine}

Chloroquine is a 4-aminoquinoline drug, and hydroxychloroquine is an analog of chloroquine, and both are used for the treatment of malaria and autoimmune diseases, respectively. Vincent et al. (2005) and Biot et al. (2006) reported the efficacy of chloroquine and hydroxychloroquine for the treatment of SARS-CoV infection during the epidemic outbreak of SARS in 2002-2003. Recently, Colson et al. (2020) reported that clinical trials on both drugs in China, South Korea, and France showed that they possess potential pharmacological activities for the treatment of COVID-19 patients.

Al-Bari (2015), Chibber et al. (2020), and Liu et al. (2020b) demonstrated that the molecular mechanisms of action of chloroquine and hydroxychloroquine drugs are similar, but they interfere with virus replication in distinct ways. They inhibit binding of the $\mathrm{S}$ proteins to host cell ACE2 receptors by blocking terminal glycosylation (Kalra et al. 2020). They increase the $\mathrm{pH}$ in intracellular compartments, ultimately inhibiting RNA replication, glycosylation of viral protein, virus assembly, and exocytosis.

According to Savarino et al. (2006), Yan et al. (2013), and Wang et al. (2020a), chloroquine is widely used as an antimalarial and autoimmune disease drug. However, recently, it has been reported as a potential broad-spectrum antiviral drug. Recently, Cortegiani et al. (2020) reported that chloroquine blocks viral infection by increasing the endosomal $\mathrm{pH}$ required for virus/cell fusion and interfering with the glycosylation of cellular receptors of SARS-CoV-1. Another recent study conducted by Wang et al. (2020b) revealed that the effective concentration (EC50) of chloroquine against SARS-CoV-2 (COVID-19) in Vero E6 cells was $6.90 \mu \mathrm{M}$, which could be clinically achieved in the plasma of patients with rheumatoid arthritis after receiving a dose of $500 \mathrm{mg}$ per day.

Chloroquine is a cheap and safe medication that has been used for more than 70 years and could potentially be clinically used against SARS-CoV-2 (COVID-19). A recent French study by Gautret et al. (2020) was carried out on SARSCoV-2-positive patients who received $600 \mathrm{mg}$ of hydroxychloroquine daily. The viral load in nasopharyngeal swabs was tested daily in hospital, and a significant reduction/ disappearance viral load was observed in the

Table 1 Drugs affecting COVID-19

\begin{tabular}{|c|c|c|c|}
\hline Drug & Mechanism of action & Dose & References \\
\hline $\begin{array}{l}\text { Chloroquine and } \\
\text { hydroxychloroquine }\end{array}$ & $\begin{array}{l}\text { A. Interfere with the virus replication in distinct } \\
\text { ways through preventing the attachment of the } \\
\text { S glycoproteins spikes on the host cell ACE-2 } \\
\text { receptors, by inhibiting the terminal } \\
\text { glycosylation } \\
\text { B. Increase the pH in the intracellular } \\
\text { compartments, ultimately inhibiting RNA } \\
\text { replication, glycosylation of viral protein, } \\
\text { virus assembly and the process of exocytosis. }\end{array}$ & $600 \mathrm{mg}$ daily, orally & $\begin{array}{l}\text { (Al-Bari 2015; } \\
\text { Cortegiani et al. } \\
\text { 2020; Gautret et al. } \\
\text { 2020; Liu et al. } \\
\text { 2020a) }\end{array}$ \\
\hline Lopinavir/ritonavir & Protease inhibitor drug & $400 \mathrm{mg} /$ for adults, 2 times/day, orally & (Dong et al. 2020a) \\
\hline Ribavirin & $\begin{array}{l}\text { Nucleoside analog antiviral drug targeting the } \\
\text { RNA-dependent polymerase enzyme of } \\
\text { SARS-CoV, MERS, and interferes with } \\
\text { replicating the viral RNA and DNA. }\end{array}$ & $500 \mathrm{mg}$ for adults, $2-3$ times/day intravenously & $\begin{array}{l}\text { (Dong et al. 2020a; } \\
\text { Khalili et al. 2020) }\end{array}$ \\
\hline Remdesivir & $\begin{array}{l}\text { Nucleoside/tide analog (adenosine analog) that } \\
\text { blocks the coronavirus RNA polymerase } \\
\text { enzymes required to replicate its genetic } \\
\text { material (RNS) and thus inhibit viral } \\
\text { proliferation in the human bodies }\end{array}$ & $\begin{array}{l}\text { The initial dose of } 200 \mathrm{mg} \text { of remdesivir and a } \\
\text { subsequent dose of } 100 \mathrm{mg} \text { for nine } \\
\text { consecutive days via intravenous infusion }\end{array}$ & $\begin{array}{l}\text { (Beigel et al. 2020; } \\
\text { Goldman et al. 2020) }\end{array}$ \\
\hline Favipiravir & $\begin{array}{l}\text { RNA-dependent RNA polymerase (RdRp) } \\
\text { inhibitor }\end{array}$ & $\begin{array}{l}\text { Day } 1,1600 \mathrm{mg} \text { twice daily; days } 2-14,600 \mathrm{mg} \\
\text { twice daily } \\
\text { Orally }\end{array}$ & (Du and Chen 2020) \\
\hline Ivermectin & Inhibition of the viral replication & $200-\mu \mathrm{g} / \mathrm{kg}$ single dose, orally & (Caly et al. 2020) \\
\hline Tocilizumab & $\begin{array}{l}\text { Antagonizing the effect of interleukin } 6 \text { (IL-6) } \\
\text { thus hindering IL-6 from exerting its } \\
\text { pro-inflammatory effect }\end{array}$ & $\begin{array}{l}\text { Either intravenously at } 8-\mathrm{mg} / \mathrm{kg} \text { body weight (up } \\
\text { to a maximum of } 800 \mathrm{mg} \text { ) in two infusions, } \\
12 \mathrm{~h} \text { apart, or subcutaneously at } 162 \mathrm{mg} \\
\text { administered in two simultaneous doses, one } \\
\text { in each thigh }\end{array}$ & (Jones et al. 2010) \\
\hline
\end{tabular}


hydroxychloroquine-treated patients. This effect was reinforced when combined with azithromycin.

Biot et al. (2006) demonstrated that hydroxychloroquine has in vitro anti-SARS-CoV activity. A recent study by Yao et al. (2020) showed that hydroxychloroquine inhibits SARSCoV-2 in vitro, with an EC50 of $0.72 \mu \mathrm{M}$. Hydroxychloroquine showed a safer clinic profile than chloroquine, allowing for a higher daily dose, particularly during long-term use, but also has obvious concerns with drug-drug interactions (Marmor et al. 2020).

\section{Lopinavir/ritonavir}

Lopinavir and ritonavir are protease inhibitors that were shown to be ineffective during the outbreaks of SARS-CoV and MERS-CoV (Pandey et al. 2020). However, they are potential drugs for the treatment of patients with SARS-CoV-2 infection (Sarkar et al. 2020). A clinical trial of lopinavir at Hong Kong University showed in vitro anti-SARS-CoV action, at a concentration of $4 \mathrm{mg} / \mathrm{ml}$ (Chu et al. 2004).

Ritonavir is used as a boosting agent. According to Stower (2020), current treatment regime guidelines recommend using lopinavir in combination with ritonavir for treatment of the COVID-19 patients. Lopinavir/ritonavir usage in the treatment of COVID-19 patients was shown to reduce the mortality rate to $2.3 \%$ from $11 \%$. Dong et al. (2020b) reported that lopinavir/ritonavir is a medication for patients with human immunodeficiency virus (HIV) that is used in combination with other medications to treat adults and children over 14 days of age, who are infected with HIV-1. The dosage of lopinavir/ritonavir permitted for COVID-19 patients is 400/ $100 \mathrm{mg}$ for adults, respectively, twice per day.

\section{Ribavirin}

Ribavirin is a nucleoside analog with broad-spectrum antiviral activity. Recent studies by Jin et al. (2020) and Khalili et al. (2020) reported that ribavirin is a nucleoside analog antiviral drug targeting the RNA-dependent polymerase enzyme of SARS-CoV and MERS-CoV that interferes with the replication of viral RNA and DNA.

It has been used in combination with corticosteroids to treat patients with SARS-CoV, hepatitis virus, and viral hemorrhagic fever, including MERS (Yousefi et al. 2020). However, studies of the in vitro and in vivo activities of ribavirin against SARS-CoV-2-infected patients did not show significant reduction/clearance of the virus. Excessive use of this drug produces distinct negative side effects, such as hemolytic anemia, hypocalcemia, and hypomagnesemia.

Currently, it is not recommended for the treatment of patients with COVID-19 (Pandey et al. 2020). However, according to the Chinese 7th edition guidelines, it is recommended for COVID-19 treatment. It is administered intravenously at a dose of $500 \mathrm{mg}$ for adults, 2-3 times/day, in combination with IFN- $\alpha$ or lopinavir/ritonavir (Dong et al. 2020b).

\section{Remdesivir}

Remdesivir is a nucleoside/tide analog with broad-spectrum antiviral activity (Goldman et al. 2020). Beigel et al. (2020) reported that this drug blocks coronavirus RNA polymerase, which is required to replicate its genetic material (RNS), and thus inhibits viral proliferation in the human body. During a clinical trial of drugs in a mouse model of SARS-CoV infection, remdesivir improved pulmonary function and reduced viral loads and the severity of lung pathology (Lem et al. 2020). The National Institutes of Health (NIH) reported that early treatment with remdesivir as an antiviral drug significantly reduced the clinical disease and reduced the lung damage of rhesus macaques (Macaca mulatta) infected with SARS-CoV-2.

On May 1, 2020, the United States Food and Drug Administration (FDA) made remdesivir available for emergency treatment for severe COVID-19 in hospitalized adults and children. Dolin and Hirsch (2020) reported that the use of remdesivir in patients with severe SARS-CoV-2 infection reduced the time of recovery from a median of 15 days among placebo recipients to 11 days. Wang et al. (2020c) found that remdesivir potently blocks SARS-CoV-2 infection at low micromolar concentrations in vitro, with an EC50 of $0.77 \mu \mathrm{M}$.

To evaluate the efficacy and safety of this drug in COVID19 patients, a phase III clinical trial was launched on February 5, 2020 in China (Diao et al. 2020). Patients in the experimental group received an initial dose of $200 \mathrm{mg}$ of remdesivir and a subsequent dose of $100 \mathrm{mg}$ for nine consecutive days via intravenous infusion in addition to routine treatments. Patients in the control group received routine treatment and the same dose of a placebo (Wang et al. 2020c). The trial results were expected to be concluded by the end of April 2020 (data not shown).

\section{Favipiravir}

Du and Chen (2020) reported that favipiravir (commercial brand name, Avigan) has been used for the treatment of influenza in Japan since 2014. Favipiravir is a new type of RNAdependent RNA polymerase (RdRp) inhibitor, and SARSCoV-2 depends on RdRp for replication inside the host cell. Recently, Delang et al. (2018) revealed that, in addition to its anti-influenza virus activity, favipiravir could also block the replication of flavi-, alpha-, filo-, bunya-, arena-, noro-, and other RNA viruses. It is converted to an active phosphoribosylated form (favipiravir-RTP) inside the cells and is recognized as a substrate by the viral RNA polymerase, thus inhibiting RNA polymerase activity (Furuta et al. 2017). 
On February 14, 2020, a clinical trial for SARS-CoV-2 (COVID-19) treatment was conducted by the National Clinical Medical Research Center for Infectious Diseases at The Third People's Hospital of Shenzhen (China). The results indicated that favipiravir had more potent antiviral action than lopinavir/ritonavir, with no significant adverse reactions in the treated group with a total of 80 patients (in the experimental and control groups) (Dong et al. 2020b).

\section{Ivermectin}

Ivermectin is an old medication that has been used to treat many types of parasitic infestations, such as head lice, scabies, river blindness, ascariasis, and lymphatic filariasis, since the 17th century, via oral administration or skin application (for external infestations) (Panahi et al. 2015). A recent study (Caly et al. 2020) revealed that ivermectin has a strong antiviral effect against SARS-CoV-2 through in vitro inhibition of viral replication (in monkey kidney VERO cell culture, with an $\mathrm{IC}_{50}$ of 2.2-2.8 $\mu \mathrm{M}$. Few more studies have indicated the potent application of ivermectin to treat COVID-19 patients (Formiga et al. 2020; Sharun et al. 2020a).

\section{Tocilizumab}

Tocilizumab was developed by Hoffmann-La Roche and Chugai. It is an immunosuppressive drug that antagonizes the effect of IL-6, a cytokine that plays important roles in the human immune response and has been implicated in the pathogenesis of many diseases. It is used mainly for the treatment of rheumatoid arthritis (RA) and systemic juvenile idiopathic arthritis (Venkiteshwaran 2009).

Tocilizumab is a humanized monoclonal antibody against the IL-6 receptor (IL-6R). Jones et al. (2010) reported that tocilizumab binds to soluble and membrane-bound IL-6 receptors, thus hindering IL-6 from exerting its proinflammatory effect. In March 2020, China and Italy approved tocilizumab to reduce inflammation in patients with COVID19. However, until now, there has been no evidence supporting the effectiveness of this drug.

\section{Use of immunomodulating drugs and proteins}

\section{Corticosteroids}

Zha et al. (2020) reported that corticosteroids are immunomodulating drugs that are frequently used in combination with other antiviral drugs. Systemic administration of corticosteroid drugs has been shown to suppress lung inflammation in 18.6-44.9\% of COVID-19 patients (Yang et al. 2020b). However, Russell et al. (2020) reported that its use in critically ill MERS-CoV and SARS-CoV patients resulted in delayed MERS-CoV and SARS-CoV RNA clearance, leading to the need for mechanical vasopressors and renal replacements.

Brown et al. (2020) demonstrated that excessive use of corticosteroid drugs is associated with psychosis, diabetes, and avascular necrosis. Thus, the use of corticosteroid drugs in the treatment of COVID-19 patients is usually not recommended, except under special circumstances (Brown et al. 2020).

\section{Interferons}

Interferons (IFNs) possess broad-spectrum antiviral activity. Thus, several interferon candidates, including type 1 alpha interferon (INF-1), have already been investigated for their potential use in the treatment of COVID-19 patients (Huang et al. 2020b; Wang et al. 2020c). Several in vitro and in vivo experiments of INF-1 for the treatment of SARS-CoV and MERS-CoV were performed in combination with lopinavir/ ritonavir, ribavirin, remdesivir, and corticosteroids (Huang et al. 2020b; Sallard et al. 2020).

The use of INF- $\alpha$ and INF- $\beta$ alone was effective in treating animals, but they failed to improve human disease. The combined use of lopinavir/ritonavir with INF- $\beta$ improved lung function but failed to reduce the viral load. However, the combination of ribavirin and IFN $\alpha 2 \alpha$ significantly reduced the mortality rate (Li and De Clercq 2020). Thus, INF-1 could be used as a prophylaxis against SARS-CoV-2. Li and De Clercq (2020) and Sallard et al. (2020) reported that the administration of 5 million units of IFN $\alpha$ in combination with ribavirin twice a day by nebulization can significantly improve the health of the COVID-19 patients.

\section{Convalescent plasma therapy}

Convalescent plasma (CP) therapy is a classic adaptive immunotherapy used in the prevention and treatment of various infectious diseases. Previous studies by Luke et al. (2006) and Arabi et al. (2015) revealed that, over the past two decades, the use of convalescent plasma with systematic corticosteroid therapy in critically ill patients with SARS-CoV, MERS-CoV, H1N1, and Ebola virus infections reduced the infection more efficiently than a placebo or no therapy.

An in vitro neutralization test performed on bronchoalveolar lavage samples from critically COVID-19 patients, using convalescent sera from patients who recovered from SARSCoV-2 infection, showed a marked neutralization effect (Thanh et al. 2020). The use of $200 \mathrm{ml}$ of convalescent plasma containing neutralizing antibody titers greater than 1:640 showed optimal results in the treatment of critically ill COVID-19 patients. Thus, CP therapy could be an alternative approach for critically COVID-19 ill patients until antivirals and vaccines are developed (Chen et al. 2020b; Sharun et al. 2020b). 


\section{Traditional herbal medicine and probiotics as treatment}

All the previously recorded data for the usage of herbal medicine and probiotics in facing COVID-19 pandemic missed the preclinical and clinical studies. Several herbal extracts from various plants, including coneflower (Echinacea), quina (Cinchona), turmeric (Curcuma longa), and temulawak (Curcuma xanthorrhiza) might have the capabilities to regulate the production and release of pro-inflammatory cytokines, interfere with the development of the virus in host cells, and modify certain molecular pathways related to the RAA system which might be useful as prevention or treatments to fight COVID-19, but this must be given carefully to patients, even if they are healthy, under the specific advice or direct supervision of a clinician.

In addition, further investigations through preclinical and clinical trial evaluations of these herbal agents for COVID-19 should be specifically conducted (Nugraha et al. 2020). Tahir et al. (2020) highlighted the potential of various nutraceuticals and herbal extracts (such as omega- 3 fats, $\beta$-glucans, amino acids, probiotics, vitamins and minerals) and plant-based compounds as possible treatments for COVID-19. Although strong evidence for the potential of these compounds to combat the ongoing COVID-19 pandemic has already appeared in their literature; clinical data are, however, still inconclusive and inconsistencies, since clinical studies did not achieve the desired effects, and these inconsistencies may be attributed to a number of factors, including the dose used, the heterogeneity of the target population, the plasma concentration, the beginning and duration of the treatment, and the route of administration.

Recently, Sytar et al. (2021) described a total of 66 medicinal herbs and crops with different origin native areas which showed antiviral potentials and mentioned that the kaempferol glycosides, the scutellarein, baicalin and quercetin flavonoids; the saikosaponins triterpenoids; the lycorine, tetrandrine, fangchinoline, and cepharanthine alkaloids; the triterpene oleanane; and the terpene cycloart-25-ene-3b,24-diol are recommended to be the most promising compounds to develop plant-based effective drugs against the current COVID-19 pandemic though preclinical studies and their clinical evidence is still missing.

Akour (2020) discussed the role of in combating COVID19 or its associated symptoms, through reviewing its antiviral and anti-inflammatory properties in vitro, animal models, and human trials and concluded that, although there is more evidence that the novel coronavirus affects gut microbiome inducing dysbiosis during its pathogenesis ( $\mathrm{Li}$ et al. 2021), the use of conventional probiotics for COVID-19 cannot be liberally recommended.

However, the modulation of gut microbiota through the use of probiotics as Lactobacillus spp., Bifidobacteria, and
Saccharomyces is expected to be one of the promising therapeutic approaches to alleviate COVID-19 and/or its associated inflammatory complications. Still, the utility of probiotics as add-on therapy may need to be further studied in welldesigned randomized controlled clinical trials to establish their efficacy and safety.

\section{Impact of COVID-19 on the environment}

COVID-19 has positive and negative indirect effects on the environment (Fig. 5). The adverse influences included the reduction in the environmental sustainability, earth systems, and the total environment (Hafez and Attia 2020; Swelum et al. 2020). The COVID is an immune response to environmental violations by humans through chemicals that are produced annually and their negative and destructive impact on the environment, its results that cannot be expected, and how to combat it, but the virus showed human weakness in facing disaster.

Most countries tried to control the expansion of SARSCoV-2 via the lockdown, strong social distancing measures, strict traffic restrictions, and self-quarantine measures. These measures cause a great reduction in the air pollution including the concentrations of nitrogen dioxide, carbon dioxide, carbon monoxide, and particulate matter that have a diameter of less than $2.5 \mu \mathrm{m}$ or less than $10 \mu \mathrm{m}$ because of reduction of use of vehicles and stoppage of the production of power plants, industrial facilities, and all businesses due to public confinement (Dantas et al. 2020; Tobías et al. 2020).

However, the level of ozone (O3) increased by more than $50 \%$ during lockdown (Tobías et al. 2020). Additionally, the lack of tourists during SARS-CoV-2 pandemic has caused a notable positive change in the cleaning and appearance of many beaches in the world. For example, the pollution of air has reduced in New York by about 50\%, and emissions have recorded a 25\% dropped in China, as well as nitrogen dioxide emissions decreased over Spain, Italy, and the UK (Scalzaretto 2020). Moreover, the noise level was reduced substantially in most countries because of the imposition of quarantine measures by most governments. The lockdown resulted also in clear water in the canals, clear skies, wild animals roaming streets, and pollution drop, particularly in the industrial areas (Capovilla 2020; Corrigan 2020; Ficetola and Rubolini 2020; Hussain et al. 2020). The lockdown during COVID-19 caused a great drop in the global consumption of oil and coal, and subsequent decrease in air pollution (IEA 2020; Ruiz 2020). This is an enhancement in environmental condition benefits COVID-19 contracts' persons. On the other hand, highly air polluted area has recorded substantial highrate of mortality due to COVID-19 (Saadat et al. 2020).

On the other hand, one of the positive consequences of COVID is changing the current economic system. For example, the export of environmentally friendly raw materials led 


\begin{tabular}{|c|}
\hline $\begin{array}{l}\text { Temperature and humidity } \\
\text { have significant adverse } \\
\text { effect on the number of daily } \\
\text { cases of COVID-19 }\end{array}$ \\
\hline $\begin{array}{l}\text { Positive significant } \\
\text { association between PM2.5, } \\
\text { pm10, co,no2 and } 03 \text { levels } \\
\text { and COVID-19 death }\end{array}$ \\
\hline $\begin{array}{l}\text { Positive significant } \\
\text { association between diurnal } \\
\text { temperature and COVID-19 } \\
\text { death }\end{array}$ \\
\hline $\begin{array}{l}\text { Negative } \begin{array}{r}\text { significant } \\
\text { between }\end{array} \\
\text { association } \\
\text { humidity and COVID-19 } \\
\text { death }\end{array}$ \\
\hline $\begin{array}{l}\text { Negative association between } \\
\text { sulfur dioxide level and } \\
\text { COVID-19 transmissions }\end{array}$ \\
\hline $\begin{array}{l}\text { Long-term exposure to } \\
\text { nitrogen dioxide increase } \\
\text { COVID-19 death }\end{array}$ \\
\hline
\end{tabular}

The impact of COVID-19 on the environments

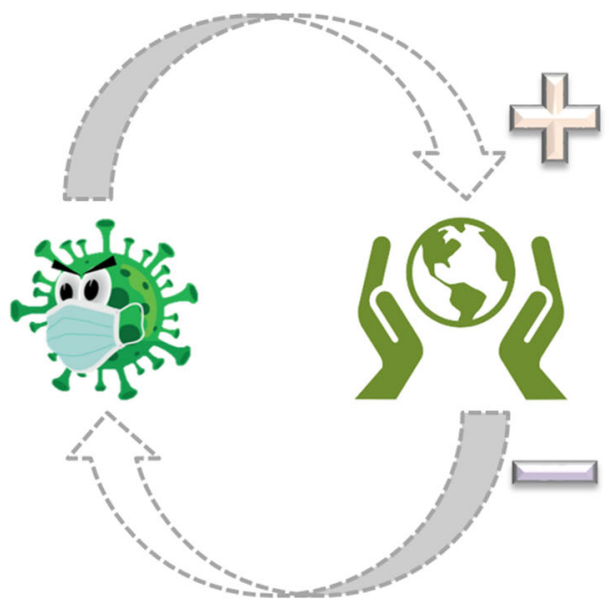

The impact of environments on COVID-19

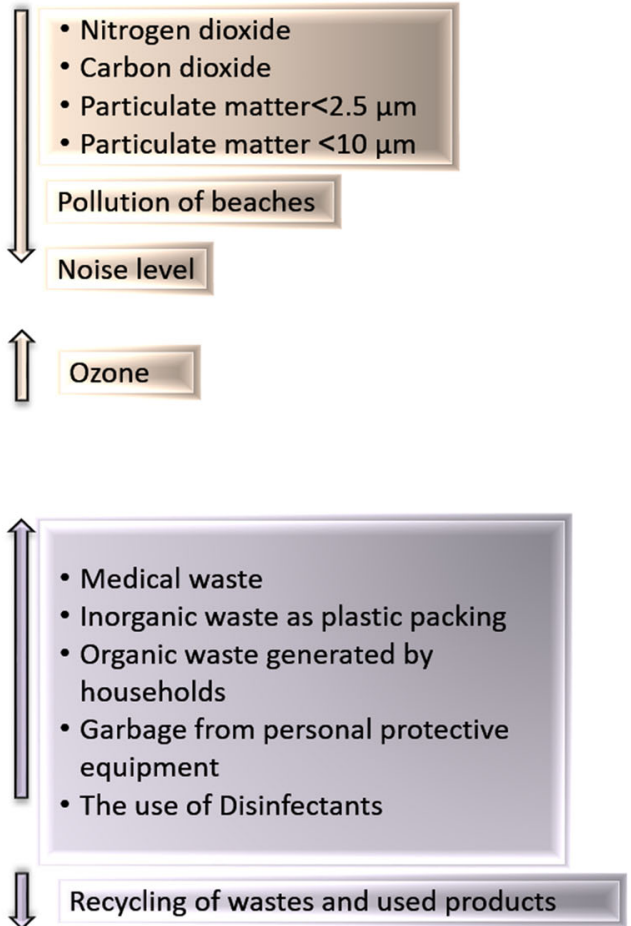

Fig. 5 The relationship between the environment and COVID-19

to the country's capital consumption and global pollution in addition to the collapse of oil prices in March 2020 (The World Bank 2020; IEA 2020; UN 2020). According to global estimates, the welfare fund will suffice for 2-3 years in conditions of low energy prices. If the development system does not change, the consequences of the next crisis could be even direr for the world (The World Bank 2020; UN 2020).

Decision-makers strive to modernize and innovate and develop intensive scientific activities and high-tech with high benefit, directing the economy to the environment. Therefore, the new economy will be less polluting (UN 2020). One of the positive effects of the virus is to reduce environmental pollution, as the economic crisis has led to the closure of institutions, the reduction of transport activity, and the decrease in the standard of living and thus will enhance the environment. It is also possible, with the continuation of the epidemic that environmental pollution will continue to break companies in the knowledge and infrastructure sector and move to primitive roads (The Interpreter, 2020; Swelum et al. 2020). There is no doubt that these positive effects on the environment will benefit the world, as the decrease in oil prices and the increase in the supply of it can be investing in it and providing an increase in it in half and providing the economy instead of investing in expensive new areas (The World Bank 2020).

Natural landmarks around the world can calmly breathe due to less tourism and low income. Excess tourism harmed the sights across the country (Aleksandrova 2018). Because of China's economic growth before the epidemic and rising income, the Chinese are spending the equivalent of $\$ 400$ billion on outbound tourism. Besides, the decrease in tourism has led to a decrement in the number of flights, thus reducing polluting gas emissions. The decrement in the number of hotels, restaurants, and transportation trips will be a friendly environment. Working online reduces transportation and urban pollution (UN 2020). The COVID pandemic has demonstrated once again the importance of bringing together and coordinating international efforts to tackle environmental problems and pushed global collaboration to safe the health and economic and/or the environment (IEA 2020; The World Bank 2020).

The negative effects of COVID-19 were associated with safety and cross-contamination. SARS-CoV-2 causes increasing medical waste, inorganic waste as single-use plastic bags, demand for bottled water, plastic packing and packaging, organic waste generated by households, and garbage from personal protective equipment such as masks and gloves (Calma 2020; Tenenbaum 2020). In addition, environmental pollution is increased due to the tendency of the poor population to use their old cars with cheap petrol that pollute the environment (Hussain et al. 2020).

Also, retail, and fast-food chains have prohibited the use of food containers and reusable cups that resulted in increasing plastic demands and waste (Zambrano-Monserrate et al. 2020). Thus, the oil industries have increased the production 
of plastics to face the increased demand and overcome economic defaults (Peszkô 2020). In addition, increasing home delivery and online shopping during lockdown deceased trash recycling to the concern about the spread of SARS-CoV-2 in recycling centers (Tenenbaum 2020). The recycling of wastes is an effective and common way to control pollution, save energy, and conserve natural resources (Varotto and Spagnolli 2017; Ma et al. 2019). Additionally, the disinfection routines are strengthened to prevent spreading of SARS-CoV2. Some of these disinfectants could generate harmful effects on people's health (Koivusalo and Vartiainen 1997). One of these disinfectants is chlorine which is used in high concentration in wastewater during COVID-19 pandemic. Based on present data, the hazard to water supplies is low. However, according to the WHO, studies of surrogate coronaviruses have indicated that the virus could remain infectious in water contaminated with feces for days to weeks (Tenenbaum 2020).

To assess the negative consequences of COVID-19, consumers' behavior is tracked based on their quality of life; it includes three components of financial well-being (wages, income, etc.), social (education, health, etc.), and the environment (clean environment, clean products, clean water, etc.). The income level determines the requirements for the three components (Kuznets curve) (Bobylev 2017). This virus harms the financial well-being, through the lack of production and the closure of institutions in the private and public sector, and consequently the decrease in income and the increase in debt and unemployment.

In the next few years, the environmental component of quality of life will decrease, thus reducing the volume of sales in all markets (Bobylev and Goryacheva 2019). In the transportation sector, there is an increase in public transportation, car sharing, and the trend to electric cars because of residents' fears of infection with the virus. It also reduces gatherings in cafes and restaurants (IEA 2020).

Environmental violations such as fishing, logging, and overfishing are also observed because of the increase in poverty. For example, on the Russian side, the BAT technological revolution that began in January 2019 is threatened with the cancellation (Skobelev 2019). The shift to low-carbon development appears to have stalled around the world as the decline in the prices of fossil fuels because of the global economic recession due to COVID was encouraged. Due to the enormous costs that countries bear in confronting COVID, their interest in sustainable development diminishes (The World Bank 2020).

\section{The impact of the environment on COVID-19}

The transmission of communicable diseases including COVID-19 is also greatly influenced by the climate parameters including temperature, humidity, rainfall, and wind speed.
Positive associations were observed between the speed of wind and crowdedness in cities with high COVID-19 transmission rates (Sahin 2020). Temperature and humidity can predict the rate COVID-19 transmission (Gupta et al. 2020).

Temperature and humidity have a significant adverse effect on the number of daily cases of COVID-19 in 30 Chinese provinces; and the interaction effect of temperature and humidity is strong in case of daily COVID-19 cases (Qin et al. 2020). When relative humidity is $67-85.5 \%$, an increasing of environmental temperature by a $1{ }^{\circ} \mathrm{C}$ in average daily temperature can decrease the daily rate of COVID-19 cases by 36$57 \%$. Similarly, when the average daily temperature is 5.04 $8.2{ }^{\circ} \mathrm{C}$, an increasing of environmental relative humidity by $1 \%$ can decrease the daily COVID-19 cases by between 11 and 22\% (Qin et al. 2020).

Additionally, a significant positive association with diurnal temperature with COVID-19 death, and a negative association between humidity and COVID-19 death, was reported by Ma et al. (2019). However, Sobral et al. (2020) found no association between temperature or precipitation and COVID-19 mortality. COVID-19 transmissions have a positive association with $\mathrm{PM}_{2.5}, \mathrm{PM}_{10}, \mathrm{CO}, \mathrm{NO}_{2}$, and ozone levels and a negative association between sulfur dioxide levels ( $\mathrm{Zhu}$ et al. 2020). Long-term exposure to $\mathrm{NO}_{2}$ increases mortality due to COVID-19 in Italy, Spain, France, and Germany (Ogen 2020).

\section{Ambiguous effects}

The unclear effects of COVID include the level of the individuality of people, as people who live in high-end areas are more vulnerable to infection than those residing in mediumquality housing in places far from urban areas (second homes). So, millions of people rushed to these places and abandoned the big cities. About half of the residents of major cities live in their homes (Skupov 2019) and according to estimates, the total number of "second homes" is around 60 million (Nefedova et al. 2016).

A rural home, where living in clean air far from cities, leads to an increase in the environmental burden in the suburbs (Khovavko 2020). To prevent environmental degradation in these areas, a payment mechanism may be implemented for ecosystem services that are increasingly used in the world (Bobylev and Goryacheva 2019).

\section{Contribution to the field}

This review aims to summarize the advanced information in the origin, evolution, genomic organization, epidemiology, and molecular and cellular characteristics of SARS-CoV-2 as well as the diagnostic and treatment approaches for COVID-19 and its environmental impact. The present status 
and future advances in vaccine development and antiviral therapies for COVID-19 treatment are discussed.

This information and data collected on SARS-CoV-2 will aid in understanding different aspects of COVID-19 and its impact on global health, environment, and the economy.

\section{Conclusions and prospects}

The emergence and spread of the new coronavirus SARSCoV-2 in 215 countries have created a serious global health threat and environmental hazards. More than 40 million people worldwide have already become victims of SARS-CoV-2, and over 1 million of these people have already lost their lives. The origin of SARS-CoV-2 is controversial, but most researchers believe that it is likely to have originated from wild bats.

Analysis of the whole genome sequences of bat and pangolin viruses showed $95 \%$ sequence identity to SARS-CoV-2. Bat and pangolins are considered to be primary natural reservoirs of SARS-CoV-2. Human transmission of this virus occurs via inhalation of respiratory droplets produced by asymptomatic and symptomatic infected people. SARS-CoV-1, MERS-CoV, and SARS-CoV-2 cause mild to severe respiratory tract infections that can lead to pneumonia.

Identification of coronavirus infections plays a crucial role in proper treatment and management and control of the pandemic outbreak, reducing the economic and environmental impact of this virus. Currently, there are no effective antiviral drugs or vaccines against SARS-CoV-2. Antiviral drugs, such as ritonavir, arbidol, remdesivir, and favipiravir, which were previously developed to treat patients infected with SARS$\mathrm{CoV}$, MERS-CoV, and Ebola, are now being used for the treatment of patients with COVID-19. Complete control of SARS-CoV-2 infection will likely only be possible after successful vaccination. However, although there is no SARSCoV-2 vaccine currently available, several are under development or in human trials.

Strict implementation of preventive and control measures such as wearing masks, washing hands, maintaining social distancing, isolation and quarantine, and surface disinfection, should help reduce the risk of infection and control the spread of SARS-CoV-2. Further research should be aimed at investigating SARS-CoV-2 in relevant animal models to dissect its replication, transmission, pathogenesis, and control. Scientists worldwide are actively exploring drugs that may be potentially effective in combating COVID-19 and controlling its spread. All stakeholders are trying to find a solution to this worldwide crisis. Finding and developing a suitable vaccine require too much time in addition to the time required for preclinical and clinical trials, governmental and organizational licensing, and production. This directs the decision-makers who face this crisis to use medications already on the market, hoping that these will have a therapeutic effect on patients with COVID-19 throughout all stages of infection.

Author contribution YA, MTE-S, AAS, SYAQ, ADA, KAA, MES, ARE, ARG, AFK, EOSH, HB-A, RT, KD, BA, SRA, KAE-T, and MEAE-H equally contributed to all stages of preparing, drafting, and writing as well in this review article. All authors read and approved the final version of this manuscript.

Data Availability All data presented herein are constant with the published literature.

\section{Declarations}

Ethical statement Not applicable.

Consent to participate Not applicable.

Consent for publication Not applicable.

Competing interests The authors declare that they have no competing interests.

\section{References}

Afzal A (2020) Molecular diagnostic technologies for COVID-19: limitations and challenges. J Adv Res 26:149-159. https://doi.org/10. 1016/j.jare.2020.08.002

Ai T, Yang Z, Hou H, Zhan C, Chen C, Lv W, Tao Q, Sun Z, Xia L (2020) Correlation of chest CT and RT-PCR testing in coronavirus disease 2019 (COVID-19) in China: a report of 1014 cases. Radiology 296:E32-E40. https://doi.org/10.1148/radiol. 2020200642

Akour A (2020) Probiotics and COVID-19: is there any link? Lett Appl Microbiol 71:229-234. https://doi.org/10.1111/lam.13334

Alagawany M, Attia YA, Farag MR et al (2020) The strategy of boosting the immune system under CoViD-19 pandemic. Front Vet Sci 7: 570748. https://doi.org/10.3389/2Ffvets.2020.570748

Al-Bari MA (2015) Chloroquine analogues in drug discovery: new directions of uses, mechanisms of actions and toxic manifestations from malaria to multifarious diseases. J Antimicrob Chemother 70:16081621. https://doi.org/10.1093/jac/dkv018

Aleksandrova AY (2018) Modern features of tourism spatial development. Geografi tur [Geograph Tour] 2:12-16 (in Russian)

Andersen KG, Rambaut A, Lipkin WI, Holmes EC, Garry RF (2020) The proximal origin of SARS-CoV-2. Nat Med 26:450-452. https://doi. org/10.1038/s41591-020-0820-9

Arabi Y, Balkhy H, Hajeer AH et al (2015) Feasibility, safety, clinical, and laboratory effects of convalescent plasma therapy for patients with Middle East respiratory syndrome coronavirus infection: a study protocol. Springerplus 4:709. https://doi.org/10.1186/ s40064-015-1490-9

Armstrong J, Niemann H, Smeekens S, Rottier P, Warren G (1984) Sequence and topology of a model intracellular membrane protein, E1 glycoprotein, from a coronavirus. Nature 308:751-752. https:// doi.org/10.1038/308751a0

Arumugam VA, Thangavelu S, Fathah Z et al (2020) COVID-19 and the world with co-morbidities of heart disease, hypertension and diabetes. J Pure Appl Microbiol 14:1623-1638. https://doi.org/10.22207/ JPAM.14.3.01 
Astuti I, Ysrafil (2020) Severe acute respiratory syndrome coronavirus 2 (SARS-CoV-2): an overview of viral structure and host response. Diabetes Metab Syndr 14:407-412. https://doi.org/10.1016/j.dsx. 2020.04.020

Attia YA, Alagawany MM, Farag MR et al (2020) Phytogenic products and phytochemicals as a candidate strategy to improve tolerance to COVID-19. Front Vet Sci 7:573-159. https://doi.org/10.3389/fvets. 2020.573159

Bardiya N, Bae JH (2005) Influenza vaccines: recent advances in production technologies. Appl Microbiol Biotechnol 67:299-305. https:// doi.org/10.1007/s00253-004-1874-1

Barrett PN, Mundt W, Kistner O, Howard MK (2009) Vero cell platform in vaccine production: moving towards cell culturebased viral vaccines. Expert Rev Vaccines 8:607-618. https://doi.org/10.1586/erv. 09.19

Beigel JH, Tomashek KM, Dodd LE, Dodd AK, Mehta BS, Zingman BS et al (2020) Remdesivir for the treatment of Covid-19-preliminary report. New Engl J Med 383:1813-1826. https://doi.org/10.1056/ NEJMoa2007764

Biot C, Daher W, Chavain N, Fandeur T, Khalife J, Dive D, De Clercq E (2006) Design and synthesis of hydroxyferroquine derivatives with antimalarial and antiviral activities. J Med Chem 49:2845-2849. https://doi.org/10.1021/jm0601856

Bobylev SN (2017) Sustainable development: paradigm for the future. Mirovaya ekonomika i mezhdunarodnye otnosheniya [World Econ Int Relat] 3:107-113 https://www.imemo.ru/en/jour/meimo/index. php?page_id $=685 \& \mathrm{id}=7822 \& \mathrm{jid}=7803 \& \mathrm{jj}=49$

Bobylev SN, Goryacheva AA (2019) Identification and assessment of eco-system services: the international context. Int Organ Res J 14: 225-236. https://doi.org/10.17323/1996-7845-2019-01-13

Broughton JP, Deng X, Yu G et al (2020) CRISPRCas12-based detection of SARS-CoV-2. Nat Biotechnol 38:870-874. https://doi.org/10. 1038/s41587-020-0513-4

Brown E, Gray R, Lo Monaco S, O'Donoghue B, Nelson B, Thompson A, Francey S, McGorry P (2020) The potential impact of COVID-19 on psychosis: a rapid review of contemporary epidemic and pandemic research. Schizophr Res Article 222:79-87. https://doi.org/ 10.1016/j.schres.2020.05.005

Calma J., 2020. https://www.theverge.com/2020/3/26/21194647/thecovid-19-pandemic-is-generating-tons-of-medical-waste

Caly L, Druce JD, Catton MG, Jans DA, Wagstaff KM (2020) The FDAapproved drug ivermectin inhibits the replication of SARSCoV-2 in vitro. Antivir Res 178:104-787. https://doi.org/10.1016/j. antiviral.2020.104787

Capovilla M. (2020) Venice's famously-polluted canals clear as tourists stay away due to COVID-19. https:/www.euronews.com/2020/03/ 16/venice-s-famously-polluted-canals-clear-as-tourists-stay-awaydue-to-covid-19

Carter LJ, Garner LV, Smoot JW et al (2020) Assay techniques and test development for COVID-19 diagnosis. ACS Cent Sci 6:591-605. https://doi.org/10.1021/acscentsci.0c00501

Cauchemez S, Van Kerkhove MD, Riley S, Donnelly CA, Fraser C, Ferguson NM (2013) Transmission scenarios for middle east respiratory syndrome coronavirus (MERS-CoV) and how to tell them apart. Euro Surveill 18:20503 PMID: 23787162

Centers for Disease Control and Prevention (CDC) (2020). https://www. cdc.gov/coronavirus/2019- ncov/lab/rt-pcr-detection-instructions. html-4

Chan JF, Kok KH, Zhu Z, Chu H, To KK, Yuan S, Yuen KY (2020) Genomic characterization of the 2019 novel human-pathogenic coronavirus isolated from a patient with atypical pneumonia after visiting Wuhan. Emerg Microbes Infect 9:221-236. https://doi.org/10. 1080/22221751.2020.1719902

Chang CK, Sue SC, Yu TH et al (2006) Modular organization of SARS coronavirus nucleocapsid protein. J Biomed Sci 13:59-72. https:// doi.org/10.1007/s11373-005-9035-9
Chen L, Xiong J, Bao L, Shi Y (2020a) Convalescent plasma as a potential therapy for COVID-19. Lancet Infect Dis 20:398-400. https:// doi.org/10.1016/s1473-3099(20)30141-9

Chen N, Zhou M, Dong X et al (2020b) Epidemiological and clinical characteristics of 99 cases of 2019 novel coronavirus pneumonia in Wuhan, China: a descriptive study. Lancet 395:507-513. https://doi. org/10.1016/S0140-6736(20)30211-7

Cheng MP, Papenburg J, Desjardins M, Kanjilal S, Quach C, Libman M, Dittrich S, Yansouni CP (2020) Diagnostic testing for severe acute respiratory syndrome-related coronavirus-2: a narrative review. Ann Intern Med 172:726-734. https://doi.org/10.7326/m20-1301

Chhikara BS, Rathi B, Singh J, Poonam FNU (2020) Corona virus SARS-CoV-2 disease COVID-19: Infection, prevention and clinical advances of the prospective chemical drug therapeutics. Chem Biol Lett 7:63-72 https://www.researchgate.net/publication/339912157

Chibber P, Haq SA, Ahmed I, Andrabi NI, Singh G (2020) Advances in the possible treatment of COVID-19: a review. Eur J Pharmacol 883:173372. https://doi.org/10.1016/j.ejphar.2020.173372

Chiocchetti R, Galiazzo G, Fracassi F, Giancola F, Pietra M (2020) ACE2 Expression in the cat and the tiger gastrointestinal taracts. Front Vet Sci 7:514. https://doi.org/10.3389/fvets.2020.00514

Chu CM, Cheng VC, Hung IF et al (2004) Role of lopinavir/ritonavir in the treatment of SARS: initial virological and clinical findings. Thorax 59:252-256. https://doi.org/10.1136/thorax.2003.012658

Colson P, Rolain JM, Raoult D (2020) Chloroquine for the 2019 novel coronavirus SARSCoV-2. Int J Antimicrob Agents 55:105923. https://doi.org/10.1016/j.ijantimicag.2020.105923

Corrigan H. (2020) Photos: clear skies and roaming wildlife abound in some of the world's most populated places. https://qz.com/1841716/ coronavirus-stay-at-home-orders-decrease-global-pollution/ ()

Cortegiani A, Ingoglia G, Ippolito M, Giarratano A, Einav S (2020) A systematic review on the efficacy and safety of chloroquine for the treatment of COVID-19. J Crit Care 57:279-283. https://doi.org/10. 1016/j.jcrc.2020.03.005

Cox MM (2012) Recombinant protein vaccines produced in insect cells. Vaccine 30:1759-1766. https://doi.org/10.1016/j.vaccine.2012.01. 016

Cui J, Li F, Shi ZL (2019) Origin and evolution of pathogenic coronaviruses. Nat Rev Microbiol 17:181-192. https://doi.org/10. 1038/s41579-018-0118-9

Dantas G, Siciliano B, França BB, da Silva CM, Arbilla G (2020) The impact of COVID-19 partial lockdown on the air quality of the city of Rio de Janeiro, Brazil. Sci Total Environ 729:139085. https://doi. org/10.1016/j.scitotenv.2020.139085

Delang L, Abdelnabi R, Neyts J (2018) Favipiravir as a potential countermeasure against neglected and emerging RNA viruses. Antivir Res 153:85-94. https://doi.org/10.1016/j.antiviral.2018.03.003

Devi YD, Goswami HB, Konwar S, et al. (2020) Potential immune epitope map for structural proteins of SARS-CoV-2. Res Square Preprint. https://doi.org/10.21203/rs.3.rs-18689/v1

Dhama K, Khan S, Tiwari R et al (2020a) Coronavirus disease 2019COVID-19. Clin Microbiol Rev 33:e0028-e00020. https://doi.org/ 10.1128/CMR.00028-20

Dhama K, Patel SK, Sharun K et al (2020b) SARS-CoV-2 jumping the species barrier: zoonotic lessons from SARS, MERS and recent advances to combat this pandemic virus. Travel Med Infect Dis 37:101830. https://doi.org/10.1016/j.tmaid.2020.101830

Dhama K, Patel SK, Pathak M et al (2020c) An update on SARS-CoV-2/ COVID-19 with particular reference to its clinical pathology, pathogenesis, immunopathology and mitigation strategies. Travel Med Infect Dis 37:101755. https://doi.org/10.1016/j.tmaid.2020.101755

Di Wu TW, Liu Q, Yang Z (2020) The SARS-CoV-2. Outbreak: what we know. Int J Infect Dis 94:44-48. https://doi.org/10.1016/j.ijid.2020. 03.004 
Diao B, Wang C, Tan Y et al (2020) Reduction and functional exhaustion of T cells in patients with coronavirus disease 2019 (COVID-19). Front Immunol 11:827. https://doi.org/10.3389/fimmu.2020.00827

Ding Y, Wang H, Shen $\mathrm{H}$ et al (2003) The clinical pathology of severe acute respiratory syndrome (SARS): a report from China. J Pathol 200:282-289. https://doi.org/10.1002/path.1440

Dolin R, Hirsch MS (2020) Remdesivir-an important first step. N Engl J Med 383:1886-1887. https://doi.org/10.1056/nejme2018715

Dong L, Hu S, Gao J (2020a) Discovering drugs to treat coronavirus disease 2019 (COVID- 19). Drug Discov Ther 14:58-60. https:// doi.org/10.5582/ddt.2020.01012

Dong Y, Mo X, Hu Y, Qi X, Jiang F, Jiang Z, Tong S (2020b) Epidemiology of COVID-19 among children in China. Pediatrics 145:e20200702. https://doi.org/10.1542/peds.2020-0702

Du YX, Chen XP (2020) Favipiravir: pharmacokinetics and concerns about clinical trials for 2019-nCoV infection. Clin Pharmacol Ther 108:242-247. https://doi.org/10.1002/cpt.1844

El Dannan H, Al Hassani M, Ramsi M (2020) Clinical course of COVID19 among immunocompromised children: a clinical case series. BMJ Case Rep 13:e237804. https://doi.org/10.1136/bcr-2020237804

Enjuanes L, Almazán F, Sola I, Zuñiga S (2006) Biochemical aspects of coronavirus replication and virus-host interaction. Annu Rev Microbiol 60:211-230. https://doi.org/10.1146/annurev.micro.60. 080805.142157

Fan BE, Chong VCL, Chan SSW, Lim GH, Lim KGE, Tan GB, Mucheli SS, Kuperan P, Ong KH (2020) Hematologic parameters in patients with COVID-19 infection. Am J Hematol 95:E131-E153. https:// doi.org/10.1002/ajh.25774

Fehr AR, Perlman S (2015) Coronaviruses: an overview of their replication and pathogenesis. Methods Mol Biol 1282:1-23. https://doi. org/10.1007/978-1-4939-2438-7_1

Ficetola GF, Rubolini D (2020) Containment measures limit environmental effects on COVID-19 early outbreak dynamics. Sci Total Environ 761:144432. https://doi.org/10.1016/j.scitotenv.2020. 144432

Florindo HF, Kleiner R, Vaskovich-Koubi D, Acúrcio RC, Carreira B, Yeini E, Tiram G, Liubomirski Y, Satchi-Fainaro R (2020) Immune-mediated approaches against COVID-19. Nat Nanotechnol 15:630-645. https://doi.org/10.1038/s41565-0200732-3

Formiga FR, Leblanc R, de Souza RJ, Farias LP, de Oliveira RN, Pena L (2020) Ivermectin: An award-winning drug with antiviral expectations against COVID-19. J Control Release. https://doi.org/10.1016/ j.jconrel.2020.10.009

Fraser C, Donnelly CA, Cauchemez S et al (2009) Pandemic potential of a strain of influenza A (H1N1): early findings. Science 324:15571561. https://doi.org/10.1126/science.1176062

Fung SY, Yuen KS, Ye ZW, Chan CP, Jin DY (2020) A tug-of-war between severe acute respiratory syndrome coronavirus 2 and host antiviral defence: lessons from other pathogenic viruses. Emerg Microbes Infect 9:558-570. https://doi.org/10.1080/22221751. 2020.1736644

Furuta Y, Komeno T, Nakamura T (2017) Favipiravir (T-705), a broadspectrum inhibitor of viral RNA polymerase. Proc Jpn Acad Ser B Phys Biol Sci 93:449-463. https://doi.org/10.2183/pjab.93.027

Garazzino S, Montagnani C, Donà D et al (2020) Multicentre Italian study of SARS-CoV-2 infection in children and adolescents, preliminary data. Euro Surveill 25:7 May 2020. https://doi.org/10.2807/ 1560-7917.es.2020.25.18.2000600

Gautret P, Lagier JC, Parola P et al (2020) Hydroxychloroquine and azithromycin as a treatment of COVID-19: results of anopenlabel non-randomized clinical trial. Int J Antimicrob Agents 56:105949. https://doi.org/10.1016/j.ijantimicag.2020.105949

Godet M, L'Haridon R, Vautherot JF, Laude H (1992) TGEV corona virus ORF4 encodes a membrane protein that is incorporated into virions. Virology 188:666-675. https://doi.org/10.1016/00426822(92)90521-p

Goldman JD, Lye DCB, Hui DS et al (2020) Remdesivir for 5 or 10 days in patients with severe covid-19. N Engl J Med 383:1827-1837. https://doi.org/10.1056/nejmoa2015301

Gorbalenya AE, Baker SC, Baric RS et al (2020) The species severe acute respiratory syndrome-related coronavirus: classifying 2019- $\mathrm{nCoV}$ and naming it SARS-CoV-2. Nat Microbiol 5:536-544. https://doi. org/10.1038/s41564-020-0695-Z

Gudadappanavar AM, Benni J (2020) An evidence-based systematic review on emerging therapeutic and preventive strategies to treat novel coronavirus (SARS-CoV-2) during an outbreak scenario. J Basic Clin Physiol Pharmacol 31:20200113. https://doi.org/10.1515/ jbcpp-2020-0113

Gupta S, Raghuwanshi GS, Chanda A (2020) Effect of weather on COVID-19 spread in the US: a prediction model for India in 2020 . Sci Total Environ 728:135560. https://doi.org/10.1016/j.scitotenv. 2020.138860

Hafez HM, Attia YA (2020) Challenges to the poultry industry: current perspectives and strategic future after the COVID-19 outbreak. Front Vet Sci 7:516. https://doi.org/10.3389/fvets.2020.00516

Hoang TN, Pino M, Boddapati AK et al (2020) Baricitinib treatment resolves lower-airway macrophage inflammation and neutrophil recruitment in SARS-CoV-2-infected rhesus macaques. Cell 184: 460-475. https://doi.org/10.1016/j.cell.2020.11.007

Huang B, Ling R, Cheng Y et al (2020a) Characteristics of the coronavirus disease 2019 and related therapeutic options. Mol Ther Methods Clin Dev 18:367-375. https://doi.org/10.1016/2Fj.omtm. 2020.06.013

Huang C, Wang Y, Li X et al (2020b) Clinical features of patients infected with 2019 novel coronavirus in Wuhan, China. Lancet 395:497506. https://doi.org/10.1016/s0140-6736(20)30183-5

Hussain S, Hussain A, Ho J, Sparagano OAE, Zia UU (2020) Economic and social impacts of COVID-19 on animal welfare and dairy husbandry in central punjab, Pakistan. Front Vet Sci 7:589971. https:// doi.org/10.3389/fvets.2020.589971

IEA (2020) International Energy Agency. Global oil demand to decline in 2020 as coronavirus weighs heavily on markets. https://www.iea. org/news/global-oil-demand-to-decline-in-2020-as-coronavirusweighs-heavily-on-markets ()

Jayawardena R, Sooriyaarachchi P, Chourdakis M, Jeewandara C, Ranasinghe P (2020) Enhancing immunity in viral infections, with special emphasis on COVID-19: a review. Diabetes Metab Syndr 14:367-382. https://doi.org/10.1016/j.dsx.2020.04.015

Jin Z, Liu JY, Feng R, Ji L, Jin ZL, Li HB (2020) Drug treatment of coronavirus disease 2019 (COVID-19) in China. Eur J Pharmacol 883:173326. https://doi.org/10.1016/j.ejphar.2020.173326

Jones G, Sebba A, Gu J et al (2010) Comparison of tocilizumab monotherapy versus methotrexate monotherapy in patients with moderate to severe rheumatoid arthritis: The AMBITION study. Ann Rheum Dis 69:88-96. https://doi.org/10.1136/ard.2008.105197

Joung J, Ladha A, Saito M, et al. (2020) Point-of-care testing for COVID19 using SHERLOCK diagnostics. medRxiv doi: https://doi.org/10. $1101 / 2020.05 .04 .20091231$

Jung K, Saif LJ (2015) Porcine epidemic diarrhea virus infection: etiology, epidemiology, pathogenesis and immunoprophylaxis. Vet J 204: 134-143. https://doi.org/10.1016/j.tvj1.2015.02.017

Kalra RS, Tomar D, Meena AS, Kandimalla R (2020) SARS-CoV-2, ACE2, and hydroxychloroquine: cardiovascular complications, therapeutics, and clinical readouts in the current settings. Pathogens 9:546. https://doi.org/10.3390/pathogens9070546

Kang S, Peng W, Zhu Y et al (2020) Recent Progress in understanding 2019 novel coronavirus associated with human respiratory disease: detection, mechanism and treatment. Int J Antimicrob Agents 55: 105950. https://doi.org/10.1016/j.ijantimicag.2020.105950 
Kaniyala Melanthota S, Banik S, Chakraborty I, Pallen S, Gopal D, Chakrabarti S, Mazumder N (2020) Elucidating the microscopic and computational techniques to study the structure and pathology of SARS-CoVs. Microsc Res Tech 83:1623-1638. https://doi.org/ 10.1002/jemt.23551

Karthik K, Aravindh Babu RP, Dhama K, Chitra MA, Kalaiselvi G, Alagesan Senthilkumar TM, Raj GD (2020) Biosafety concerns during the collection, transportation, and processing of COVID-19 samples for diagnosis. Arch Med Res 51:623-630. https://doi.org/ 10.1016/j.arcmed.2020.08.007

Keam S, Megawati D, Patel SK, Tiwari R, Dhama K, Harapan H (2020) Immunopathology and immunotherapeutic strategies in severe acute respiratory syndrome coronavirus 2 infection. Rev Med Virol 30: e2123. https://doi.org/10.1002/rmv.2123

Khalili JS, Zhu H, Mak NSA, Yan Y, Zhu Y (2020) Novel coronavirus treatment with ribavirin: groundwork for an evaluation concerning COVID-19. J Med Virol 92:740-746. https://doi.org/10.1002/jmv. 25798

Khan A, Umbreen S, Hameed A et al (2020) In silico mutagenesis based remodeling of SARs-CoV-1 peptide (ATLQAIAS) to Iinhibit SARs-CoV-2: structural-dynamics and free energy calculations. Res Square. https://doi.org/10.21203/rs.3.rs-76731/v1

Khovavko IY (2020) Economic analysis of "garbage conflicts" (the example of modern Russia). Ehkonomicheskaya nauka sovremennoi Rossii [Economics of contemporary Russia] 1:55-67. https://doi. org/10.33293/1609-1442-2020-1(88)-55-67 (in Russian)

Kolifarhood G, Aghaali M, Mozafar Saadati H, Taherpour N, Rahimi S, Izadi N, Hashemi Nazari SS (2020) Epidemiological and clinical aspects of COVID-19; a narrative review. Arch Acad Emerg Med 8:e41 https://www.researchgate.net/deref/http\%3A\%2F\%2Fdx.doi. org\%2F10.22037\%2Faaem.v8i1.620

Koivusalo M, Vartiainen T (1997) Drinking water chlorination byproducts and cancer. Rev Environ Health 12:81-90

Konda M, Dodda B, Konala VM, Naramala S, Adapa S (2020) Potential zoonotic origins of SARS-CoV-2 and insights for preventing future pandemics through one health approach. Cureus 12:e8932. https:// doi.org/10.7759/2Fcureus. 8932

Kreiter S, Diken M, Selmi A, Türeci Ö, Sahin U (2011) Tumor vaccination using messenger RNA: prospects of a future therapy. Curr Opin Immunol 23:399-406. https://doi.org/10.1016/j.coi.2011.03.007

Kubina R, Dziedzic A (2020) Molecular and serological tests for COVID-19 a comparative review of SARS-CoV-2 coronavirus laboratory and point-of-care diagnostics. Diagnostics 10:434. https:// doi.org/10.3390/diagnostics10060434

Kumar S, Nyodu R, Maurya VK, Saxena SK (2020) Morphology, genome organization, replication, and pathogenesis of severe acute respiratory syndrome coronavirus 2 (SARS-CoV-2). Coronavirus Disease 2019 (COVID-19):23-31. https://doi.org/10.1007/2F978981-15-4814-7 3

Lai CC, Shih TP, Ko WC, Tang HJ, Hsueh PR (2020) Severe acute respiratory syndrome coronavirus 2 (SARS-CoV-2) and corona virus disease-2019 (COVID-19): the epidemic and the challenges. Int J Antimicrob Agents 55:105924. https://doi.org/10.1016/j. ijantimicag.2020.105924

Ledford H (2020) Coronavirus breakthrough: dexamethasone is first drug shown to save lives. Nature. 582:469. https://doi.org/10.1038/ d41586-020-01824-5

Lee PI, Hu YL, Chen PY, Huang YC, Hsueh PR (2020a) Are children less susceptible to COVID-19? J Microbiol Immunol Infect 53:371372. https://doi.org/10.1016/j.jmii.2020.02.011

Lee EYP, Ng MY, Khong PL (2020b) COVID-19 pneumonia: what has CT taught us? Lancet Infect Dis 20:384-385. https://doi.org/10. 1016/s1473-3099(20)30134-1

Lem FF, Opook F, Herng DLJ, Na CS, Lawson FP, Tyng CF (2020) Molecular mechanism of action of repurposed drugs and traditional Chinese medicine used for the treatment of patients infected with
COVID-19: a systematic review. medRxiv https://doi.org/10.1101/ 2020.04.10.20060376

Leung GM, Hedley AJ, Ho LM et al (2004) The epidemiology of severe acute respiratory syndrome in the 2003 Hong Kong epidemic: an analysis of all 1755 patients. Ann Intern Med 141:662-673. https:// doi.org/10.7326/0003-4819-141-9-200411020-00006

Li D, Zhao MY, Malcolm TH (2021) What makes a foodborne virus: comparing coronaviruses with human noroviruses. Curr Opin Food Sci 42:1-7. https://doi.org/10.1016/2Fj.cofs.2020.04.011

Li G, De Clercq E (2020) Therapeutic options for the 2019 novel coronavirus (2019-nCoV). Nat Rev Drug Discov 19:149-151. https:// doi.org/10.1038/d41573-020-00016-0

Li H, Liu SM, Yu XH, Tang SL, Tang CK (2020) Coronavirus disease 2019 (COVID-19): current status and future perspective. Int J Antimicrob Agents 55:105951. https://doi.org/10.1016/j. ijantimicag.2020.105951

Li W, Moore MJ, Vasilieva N et al (2003) Angiotensin converting enzyme 2 is a functional receptor for the SARS coronavirus. Nature 426:450-454. https://doi.org/10.1038/nature02145

Li YH, Hu CY, Wu NP, Yao HP, Li LJ (2019) Molecular characteristics, functions, and related pathogenicity of MERS-CoV proteins. Engineering (Beijing) 5:940-947. https://doi.org/10.1016/j.eng. 2018.11.035

Liljeqvist S, Ståhl S (1999) Production of recombinant subunit vaccines: protein immunogens, live delivery systems and nucleic acid vaccines. J Biotechnol 73:1-33. https://doi.org/10.1016/s01681656(99)00107-8

Liu MA (2003) DNA vaccines: a review. J Intern Med 253:402-410. https://doi.org/10.1046/j.1365-2796.2003.01140.x

Liu J, Cao R, Xu M, Wang X, Zhang H, Hu H, Li Y, Hu Z, Zhong W, Wang M (2020a) Hydroxychloroquine, a less toxic derivative of chloroquine, is effective in inhibiting SARS-CoV-2 infection in vitro. Cell Discov 6:16. https://doi.org/10.1038/s41421-0200156-0

Liu Y, Gayle AA, Wilder-Smith A, Rocklöv J (2020b) The reproductive number of COVID-19 is higher compared to SARS coronavirus. J Travel Med 27:taaa021. https://doi.org/10.1093/jtm/taaa021

Luke TC, Kilbane EM, Jackson JL, Hoffman SL (2006) Meta-analysis: convalescent blood products for Spanish influenza pneumonia: a future H5N1 treatment? Ann Intern Med 145:599-609. https://doi. org/10.7326/0003-4819-145-8-200610170-00139

Ma B, Li X, Jiang Z, Jiang J (2019) Recycle more, waste more? When recycling efforts increase resource consumption. J Clean Prod 206: 870-877 https://www.x-mol.com/paperRedirect/835878

Malik YS, Kumar N, Sircar S et al (2020) Coronavirus disease pandemic (COVID-19): challenges and a global perspective. Pathogens 9:519. https://doi.org/10.3390/pathogens9070519

Mardani R, Ahmadi Vasmehjani A, Zali F, Gholami A, Mousavi Nasab SD, Kaghazian H, Kaviani M, Ahmadi N (2020) Laboratory parameters in detection of COVID-19 patients with positive RT-PCR; a diagnostic accuracy study. Arch Acad Emerg Med 8:e43 PMID: 32259132

Marmor MF, Carr RE, Easterbrook M, Farjo AA, Mieler WF (2020) Recommendations on screening for chloroquine and hydroxychloroquine retinopathy: a report by the American Academy of Ophthalmology. Ophthalmol 109:1377-1382. https:// doi.org/10.1016/s0161-6420(02)01168-5

Moderna C. (2020) Moderna announces funding award from CEPI to accelerate development of messenger RNA (mRNA) vaccine against novel coronavirus. https://investors.modernatx.com/ newsreleases/news-release-details/moderna-announcesfundingaward-cepi-accelerate-development/

Mousavizadeh L, Ghasemi S (2020) Genotype and phenotype of COVID-19: Their roles in pathogenesis. J Microbiol Immunol Infect. https://doi.org/10.1016/j.jmii.2020.03.022 
Müller NL, Ooi GC, Khong PL, Nicolaou S (2003) Severe acute respiratory syndrome: radiographic and $\mathrm{CT}$ findings. AJR Am J Roentgenol 181:3-8. https://doi.org/10.2214/ajr.181.1.1810003

Nefedova TG, Averkieva KV, Makhrova AG [Eds] (2016) Between the home and home. Return spatial mobility of the population of Russia. A new chronograph. Moscow. https://doi.org/10.15356/ BHAH2016 (in Russian)

Ni W, Yang X, Yang D et al (2020) Role of angiotensin-converting enzyme $2\left(\mathrm{ACE}_{2}\right)$ in COVID-19. Crit Care 24:422. https://doi.org/ 10.1186/s13054-020-03120-0

Nugraha RV, Ridwansyah H, Ghozali M, Khairani AF, Atik N (2020) Traditional herbal medicine candidates as complementary treatments for COVID-19: a review of their mechanisms, pros and cons. Evid Based Complement Alternat Med 2020:2560645. https://doi. org $/ 10.1155 / 2020 / 2560645$

Ogen Y (2020) Assessing nitrogen dioxide $\left(\mathrm{NO}_{2}\right)$ levels as a contributing factor to coronavirus (COVID-19) fatality. Sci Total Environ 726: 138605. https://doi.org/10.1016/j.scitotenv.2020.138605

Omolo CA, Soni N, Fasiku VO, Mackraj I, Govender T (2020) Update on therapeutic approaches and emerging therapies for SARS-CoV-2 virus. Eur J Pharmacol 883:173348. https://doi.org/10.1016/j. ejphar.2020.173348

Onder G, Rezza G, Brusaferro S (2020) Case-fatality rate and characteristics of patients dying in relation to COVID-19 in Italy. JAMA 323: 1775-1776. https://doi.org/10.1001/jama.2020.4683

Pachetti M, Marini B, Benedetti F et al (2020) Emerging SARSCoV-2 mutation hot spots include a novel RNA dependent-RNA polymerase variant. J Transl Med 18:179. https://doi.org/10.1186/s12967020-02344-6

Pal M, Berhanu G, Desalegn C, Kandi V (2020) Severe acute respiratory syndrome Coronavirus-2 (SARS-CoV-2): An update. Cureus 12: e7423. https://doi.org/10.7759/cureus.7423

Pan X, Dong L, Yang N, Chen D, Peng C (2020) Potential drugs for the treatment of the novel coronavirus pneumonia (COVID-19) in China. Virus Res 286:198057. https://doi.org/10.1016/j.virusres. 2020.198057

Panahi Y, Poursaleh Z, Goldust M (2015) The efficacy of topical and oral ivermectin in the treatment of human scabies. Ann Parasitol 61:1116 PMID: 25911032

Pandey A, Nikam AN, Shreya AB et al (2020) Potential therapeutic targets for combating SARS-CoV-2: drug repurposing, clinical trials and recent advancements. Life Sci 256:117883. https://doi.org/10. $1016 / j .1 f s .2020 .117883$

Patel SK, Saikumar G, Rana J, Dhama J, Yatoo MI, Tiwari R, RodríguezMorales AJ, Dhama K (2020) Dexamethasone: a boon for critically ill COVID-19 patients? Travel Med Infect Dis 37:101844. https:// doi.org/10.1016/j.tmaid.2020.101844

Peszkô G (2020) Plastics: the coronavirus could reset the clock. https:// blogs.worldbank.org/voices/plastics-coronavirus-could-reset-clock

Plotkin SA (2005) Vaccines: past, present and future. Nat Med 11:S5S11. https://doi.org/10.1038/nm1209

Pooladanda V, Thatikonda S, Godugu C (2020) The current understanding and potential therapeutic options to combat COVID-19. Life Sci 1 254:117765. https://doi.org/10.1016/j.lfs.2020.117765

Prompetchara E, Ketloy C, Palaga T (2020) Immune responses in COVID-19 and potential vaccines: lessons learned from SARS and MERS epidemic. Asian Pac J Allergy Immunol 38:1-9. https://doi.org/10.12932/ap-200220-0772

Qin C, Zhou L, Hu Z, Zhang S, Yang S, Tao Y, Xie C, Ma K, Shang K, Wang W, Tian DS (2020) Dysregulation of immune response in patients with coronavirus 2019 (COVID-19) in Wuhan, China. Clin Infect Dis 71:762-768. https://doi.org/10.1093/cid/ciaa248

Qun L (2020) The 2019-nCoV outbreak joint field epidemiology investigation team. An outbreak of NCIP (2019- nCoV) infection in
China-Wuhan, Hubei Province, 2019-2020. China CDC Weekly Report 2(5):79-80

Rabaan AA, Al-Ahmed SH, Sah R et al (2020) SARS-CoV-2/COVID-19 and advances in developing potential therapeutics and vaccines to counter this emerging pandemic. Ann Clin Microbiol Antimicrob 19:40. https://doi.org/10.1186/s12941-020-00384-w

Raoult D, Zumla A, Locatelli F, Ippolito G, Kroemer G (2020) Coronavirus infections: epidemiological, clinical and immunological features and hypotheses. Cell Stress 4:66-75. https://doi.org/10. $15698 /$ cst2020.04.216

Read JM, Bridgen JR, Cummings DA, Ho A, Jewell CP (2020) Novel coronavirus 2019- nCoV: early estimation of epidemiological parameters and epidemic predictions. medRxiv 20018549. https://doi. $\operatorname{org} / 10.1101 / 2020.01 .23 .20018549$

Rodrigues JCL, Hare SS, Edey A, Devaraj A, Jacob J, Johnstone A, McStay R, Nair A, Robinson G (2020) An update on COVID-19 for the radiologist - a British Society of Thoracic Imaging statement. Clin Radiol 75:323-325. https://doi.org/10.1016/j.crad.2020.03.003

Ruiz M. (2020) An unintended consequence of COVID-19 shutdowns? Blue skies and cleaner air. https://www.vogue.com/article/ coronavirus-environmental-impact-pollution ()

Russell CD, Millar JE, Baillie JK (2020) Clinical evidence does not support corticosteroid treatment for 2019-nCoV lung injury. Lancet 395:473-475. https://doi.org/10.1016/s0140-6736(20) 30317-2

Saadat S, Rawtani D, Hussain CM (2020) Environmental perspective of COVID-19. Sci Total Environ 728:138870. https://doi.org/10.1016/ j.scitotenv.2020.138870

Sahin M (2020) Impact of weather on COVID-19 pandemic in Turkey. Sci Total Environ 728:138810. https://doi.org/10.1016/j.scitotenv. 2020.138810

Salehi S, Abedi A, Balakrishnan S, Gholamrezanezhad A (2020) Coronavirus disease 2019 (COVID-19): a systematic review of imaging findings in 919 patients. AJR Am J Roentgenol 215:87-93. https://doi.org/10.2214/ajr.20.23034

Sallard E, Lescure FX, Yazdanpanah Y, Mentre F, Peiffer-Smadja N (2020) Type 1 interferons as a potential treatment against COVID19. Antivir Res 178:104791. https://doi.org/10.1016/j.antiviral. 2020.104791

Samaddar A, Grover M, Nag VL (2020) Pathophysiology and potential therapeutic candidates for COVID-19: a poorly understood arena. Front Pharmacol 11:585888. https://doi.org/10.3389/fphar.2020. 585888

Sarkar C, Mondal M, Torequl Islam M, Martorell M, Docea AO, Maroyi A, Sharifi-Rad J, Calina D (2020) Potential therapeutic options for COVID-19: current status, challenges, and future perspectives. Front Pharmacol 11:1428. https://doi.org/10.3389/fphar.2020. 572870

Savarino A, Di Trani L, Donatelli I, Cauda R, Cassone A (2006) New insights into the antiviral effects of chloroquine. Lancet Infect Dis 6 : 67-69. https://doi.org/10.1016/s1473-3099(06)70361-9

Scalzaretto N. (2020) World health organization suspends chloroquine trials. The Brazilian report. https://brazilian.report/coronavirusbrazil-live-blog/ ()

Schijns V, Lavelle EC (2020) Prevention and treatment of COVID-19 disease by controlled modulation of innate immunity. Eur $\mathrm{J}$ Immunol 50:932-938. https://doi.org/10.1002/eji.202048693

Shang J, Ye G, Shi K, Wan Y, Luo C, Aihara H, Geng Q, Auerbach A, Li F (2020) Structural basis of receptor recognition by SARS-CoV-2. Nature 581:221-224. https://doi.org/10.1038/s41586-020-2179-y

Sharun K, Dhama K, Patel SK et al (2020a) Ivermectin, a new candidate therapeutic against SARS-CoV-2/COVID-19. Version 2. Ann Clin Microbiol Antimicrob 19:23. https://doi.org/10.1186/s12941-02000368-w

Sharun K, Tiwari R, Yatoo I et al (2020b) Antibody-based immunotherapeutics and use of convalescent plasma to counter COVID-19: 
advances and prospects. Expert Opin Biol Ther 20:1033-1046. https://doi.org/10.1080/14712598.2020.1796963

Shi H, Han X, Jiang N, Cao Y, Alwalid O, Gu J, Fan Y, Zheng C (2020) Radiological findings from 81 patients with COVID-19 pneumonia in Wuhan, China: a descriptive study. Lancet Infect Dis 20:425434. https://doi.org/10.1016/S1473-3099(20)30086-4

Shi Y, Wang G, Cai XP, Deng JW, Zheng L, Zhu HH (2019) 冠状病毒病 (COVID-19) 概览 (英文). J Zhejiang Univ-Sci B (Biomed Biotechnol) 5

Singal CMS, Jaiswal P, Seth P (2020) SARS-CoV-2 more than a respiratory virus: Its potential role in neuropathogenesis. ACS Chem Neurosci 11:1887-1899. https://doi.org/10.1021/acschemneuro. 0c00251

Skariyachan S, Challapilli SB, Packirisamy S, Kumargowda ST, Sridhar VS (2019) Recent aspects on the pathogenesis mechanism, animal models and novel therapeutic interventions for middle east respiratory syndrome coronavirus infections. Front Microbiol 10:569-587. https://doi.org/10.3389/fmicb.2019.00569

Skobelev DO (2019) Environmental industrial policy: major directions and principles of its development in Russia. Vestnik Moskovskogo Univ [J Moscow Unive] Series 6 Econ 4:78-94 (in Russian)

Skupov B (2019) No good luck without dacha. An essay in favour of the national symbol of Russian lifestyle. https://ardexpert.ru/article/ 15748 (in Russian)

Sobral MFF, Duarte GB, da Penha Sobral AIG, Marinho MLM, de Souza MA (2020) Association between climate variables and global transmission oF SARS-CoV-2. Sci Total Environ 729:138997. https:// doi.org/10.1016/j.scitotenv.2020.138997

Sohag AAM, Hannan MA, Rahman S, Hossain M, Hasan M, Khan MK, Khatun A, Dash R, Uddin MJ (2020) Revisiting potential druggable targets against SARS-CoV-2 and repurposing therapeutics under preclinical study and clinical trials: a comprehensive review. Drug Dev Res. https://doi.org/10.1002/ddr.21709

Stower H (2020) Lopinavir-ritonavir in severe COVID-19. Nat Med 26: 465. https://doi.org/10.1038/s41591-020-0849-9

Swelum AA, Shafi ME, Albaqami NM et al (2020) COVID-19 in Human, animal, and environment: a review. Front Vet Sci 7:578. https://doi.org/10.3389/fvets.2020.00578

Sytar O, Brestic M, Hajihashemi S, Skalicky M, Jan K, Lamilla-Tamayo L, Ibrahimova U, Ibadullayeva S, Landi M (2021) COVID-19 prophylaxis efforts based on natural antiviral plant extracts and their compounds. Molecules 26:727. https://doi.org/10.3390/ molecules 26030727

Tahir AH, Javed MM, Hussain Z (2020) Nutraceuticals and herbal extracts: a ray of hope for COVID-19 and related infections (Review). Int J Funct Nutr 1:6. https://doi.org/10.3892/ijfn.2020.6

Tenenbaum L. (2020) The amount of plastic waste is surging because of the coronavirus pandemic. https://www.forbes.com/sites/ lauratenenbaum/2020/04/25/plastic-waste-during-the-time-ofCOVID-19/\#1e87efb67e48 ().

Thanh LT, Andreadakis Z, Kumar A, Gómez Román R, Tollefsen S, Saville M, Mayhew S (2020) The COVID-19 vaccine development landscape. Nat Rev Drug Discov 19:305-306. https://doi.org/10. 1038/d41573-020-00073-5

The World Bank (2020). Impact of COVID-19 on commodity markets heaviest on energy prices; lower oil demand likely to persist beyond 2021. https://www.worldbank.org/en/news/press-release/2020/10/ 22/impact-of-covid-19-on-commodity-markets-heaviest-on-energyprices-lower-oil-demand-likely-to-persist-beyond-2021.

Tian S, Xiong Y, Liu H, Niu L, Guo J, Liao M, Xiao SY (2020) Pathological study of the 2019 novel coronavirus disease (COVID-19) through postmortem core biopsies. Mod Pathol 33: 1007-1014. https://doi.org/10.1038/s41379-020-0536-x

Tiwari R, Dhama K, Sharun K et al (2020) COVID-19: animals, veterinary and zoonotic links. Vet Q 40:169-182. https://doi.org/10.1080/ 01652176.2020 .1766725
Tobías A, Carnerero C, Reche C, Massagué J, Via M, Minguillón MC, Alastuey A, Querol X (2020) Changes in air quality during the lockdown in Barcelona (Spain) one month into the SARS-CoV-2 epidemic. Sci Total Environ 726:138540. https://doi.org/10.1016/j. scitotenv.2020.138540

United Nation, UN (2020). Impact of COVID-19 pandemic on trade and development, transitioning to a new normal. United Nations Conference on Trade And Development https://unctad.org/system/ files/official-document/osg2020d1_en.pdf.

Vabret N, Britton GJ, Gruber C et al (2020) Immunology of COVID-19: current state of the science (review). Immunity 52:910-941. https:// doi.org/10.1016/j.immuni.2020.05.002

Varotto A, Spagnolli A (2017) Psychological strategies to promote household recycling. A systematic review with meta-analysis of validated field interventions. J Environ Psychol 51:168-188. https://doi.org/10.1016/j.jenvp.2017.03.011

Vellingiri B, Jayaramayya K, Iyer M et al (2020) COVID-19: a promising cure for the global panic. Sci Total Environ 725:138277. https://doi. org/10.1016/j.scitotenv.2020.138277

Venkiteshwaran A (2009) Tocilizumab. MAbs 1:432-438. https://doi. org/10.4161/mabs.1.5.9497

Verity R, Okell LC, Dorigatti I et al (2020) Estimates of the severity of coronavirus disease 2019: a model based analysis. Lancet Infect Dis 20:669-677. https://doi.org/10.1016/s1473-3099(20)30243-7

Vincent MJ, Bergeron E, Benjannet S, Erickson BR, Rollin PE, Ksiazek TG, Seidah NG, Nichol ST (2005) Chloroquine is a potent inhibitor of SARS coronavirus infection and spread. Virol J 2:69. https://doi. org/10.1186/1743-422x-2-69

Walls AC, Park YJ, Tortorici MA, Wall A, Mcguire AT, Veesler D (2020) Structure, function and antigenicity of the SARS-CoV-2 spike glycoprotein. Cell 181:281-292. https://doi.org/10.1016/j. cell.2020.02.058

Wang B, Li D, Liu T, Wang H, Luo F, Liu Y (2020a) Subcutaneous injection of interferon- $\alpha 2 b$ for COVID-19: an observational study. BMC Infect Dis 20:723. https://doi.org/10.1186/s12879-02005425-5

Wang M, Cao R, Zhang L et al (2020b) Remdesivir and chloroquine effectively inhibit the recently emerged novel coronavirus (2019$\mathrm{nCoV}$ ) in vitro. Cell Res 30:269-271. https://doi.org/10.1038/ s41422-020-0282-0

Wang Y, Zhang D, Du G et al (2020c) Remdesivir in adults with severe COVID-19: a randomized, double-blind, placebo-controlled, multicenter trial. Lancet 395:1569-1578. https://doi.org/10.1016/s01406736(20)31022-9

World Health Organization (WHO). (2003) Summary table of SARS cases by country https://www.who.int/csr/sars/country/ country2003_08_15.pdf?ua=1.

World Health Organization (WHO) (2020) Novel coronavirus diseases (COVID-19). https://covid19.who.int/.

World Health Organization (WHO) (2021) Draft landscape of COVID19 candidate vaccines - 29 January 2021. https://www.who.int/ publications $/ \mathrm{m} /$ item/draft-landscape-of-covid-19-candidatevaccines

Wu A, Peng Y, Huang B et al (2020) Genome composition and divergence of the novel coronavirus $(2019-\mathrm{nCoV})$ originating in China. Cell Host Microbe 27(3):325-328. https://doi.org/10.1016/j.chom. 2020.02.001

Xia S, Zhu Y, Liu M et al (2020) Fusion mechanism of 2019-nCoV and fusion inhibitors targeting HR1 domain in spike protein. Cell Mol Immunol 17:765-767. https://doi.org/10.1038/s41423-020-0374-2

Xiu S, Dick A, Ju H, Mirzaie S, Abdi F, Cocklin S, Zhan P, Liu X (2020) Inhibitors of SARS-CoV-2 entry: current and future opportunities. J Med Chem 63:12256-12274. https://doi.org/10.1021/acs. jmedchem.0c00502

Xu X, Chen P, Wang J, Feng J, Zhou H, Li X, Zhong W, Hao P (2020a) Evolution of the novel coronavirus from the ongoing Wuhan 
outbreak and modeling of its spike protein for risk of human transmission. Sci China Life Sci 63:457-460. https://doi.org/10.1007/ s11427-020-1637-5

Xu X, Yu C, Zhang L, Luo L, Liu J (2020b) Imaging features of 2019 novel coronavirus pneumonia. Eur J Nucl Med Mol Imaging 47: 1022-1023. https://doi.org/10.1007/s00259-020-04720-2

Yan Y, Zou Z, Sun Y, Li X, Xu KF, Wei Y, Jiang C (2013) Anti-malaria drug chloroquine is highly effective in treating avian influenza $\mathrm{A}$ H5N1 virus infection in an animal model. Cell Res 23:300-302. https://doi.org/10.1038/cr.2012.165

Yang X, Yu Y, Xu J, Shu H, Xia J et al (2020a) Clinical course and outcomes of critically ill patients with SARS-CoV-2 pneumonia in Wuhan, China: a single-centered, retrospective, observational study. Lancet Respir Med 8:475-481. https://doi.org/10.1016/S22132600(20)30079-5

Yang Y, Peng F, Wang R, Yange M, Guan K, Jiang T, Xu G, Sun J, Chang C (2020b) The deadly coronaviruses: The 2003 SARS pandemic and the 2020 novel coronavirus epidemic in China. J Autoimmun 109:102434. https://doi.org/10.1016/j.jaut.2020. 102434

Yao X, Ye F, Zhang M et al (2020) In vitro antiviral activity and projection of optimized dosing design of hydroxychloroquine for the treatment of severe acute respiratory syndrome coronavirus 2 (SARSCoV-2). Clin Infect Dis 71:732-739. https://doi.org/10.1093/cid/ ciaa237

Yatoo MI, Hamid Z, Parray OR et al (2020) COVID-19 - recent advancements in identifying novel vaccine candidates and current status of upcoming SARS-CoV-2 vaccines. Hum Vaccin Immunr 16:28912904. https://doi.org/10.1080/21645515.2020.1788310

Yousefi B, Valizadeh S, Ghaffari H, Vahedi A, Karbalaei M, Eslami M (2020) A global treatments for coronaviruses including COVID-19. J Cell Physiol 235:9133-9142. https://doi.org/10.1002/jcp.29785

Yu J, Chai P, Ge S, Fan X (2020) Recent understandings toward coronavirus disease 2019 (COVID-19): from bench to bedside. Front Cell Dev Biol 8:476. https://doi.org/10.3389/fcell.2020.00476
Yuan S, Jiang SC, Li ZL (2020) Analysis of possible intermediate hosts of the new coronavirus SARS-CoV-2. Front Vet Sci 7:379. https:// doi.org/10.3389/fvets.2020.00379

Zambrano-Monserrate MA, Ruano MA, Sanchez-Alcalde L (2020) Indirect effects of COVID-19 on the environment. Sci Total Environ 728:138813. https://doi.org/10.1016/j.scitotenv.2020. 138813

Zha L, Li S, Pan L, Tefsen B, Li Y, French N, Chen L, Yang G, Villanueva EV (2020) Corticosteroid treatment of patients with coronavirus disease 2019 (COVID-19). Med J Aust 212:416-420. https://doi.org/10.5694/mja2.50577

Zhang H, Zhou P, Wei Y et al (2020a) Histopathologic changes and SARS-CoV-2 immunostaining in the lung of a patient with COVID-19. Ann Intern Med 172:629-632. https://doi.org/10. 7326/m20-0533

Zhang J, Xie B, Hashimoto K (2020b) Current status of potential therapeutic candidates for the COVID-19 crisis. Brain Behav Immun 87: 59-73. https://doi.org/10.1016/j.bbi.2020.04.046

Zhang T, Wu Q, Zhang Z (2020c) Probable pangolin homology associated with 2019-nCoV. Curr Biol 30:1346-1135. https://doi.org/10. 1016/j.cub.2020.03.022

Zhou P, Yang XL, Wang XG et al (2020) A pneumonia outbreak associated with a new coronavirus of probable bat origin. Nature 588(7836):E6. https://doi.org/10.1038/s41586-020-2951-z

Zhu Y, Xie J, Huang F, Cao L (2020) Association between short-term exposure to air pollution and COVID-19 infection: evidence from China. Sci Total Environ 727:138704. https://doi.org/10.1016/j. scitotenv.2020.138704

Zumla A, Chan JF, Azhar EI, Hui DS, Yuen KY (2016) Coronaviruses drug discovery and therapeutic options. Nat Rev Drug Discov 15: 327-347. https://doi.org/10.1038/nrd.2015.37

Publisher's note Springer Nature remains neutral with regard to jurisdictional claims in published maps and institutional affiliations.

\section{Affiliations}

Youssef A. Attia ${ }^{1,2,3}$ (1) $\cdot$ Mohamed T. El-Saadony ${ }^{4} \cdot$ Ayman A. Swelum $^{5,6}$ (D) $\cdot$ Shaza Y.A. Qattan ${ }^{7} \cdot$ Adel D. Al-qurashi $^{1}$. Khalid A. Asiry ${ }^{1} \cdot$ Manal E. Shafi ${ }^{8}$ - Ahmed R. Elbestawy ${ }^{9}$. Ahmed R. Gado ${ }^{9} \cdot$ Asmaa F. Khafaga $^{10}$. Elsayed O.S. Hussein ${ }^{5} \cdot$ Hani Ba-Awadh ${ }^{5} \cdot$ Ruchi Tiwari $^{11} \cdot$ Kuldeep Dhama $^{12} \cdot$ Bakr Alhussaini $^{13} \cdot$ Salem R. Alyileili $^{14}$. Khaled A. El-Tarabily ${ }^{15,16}$ • Mohamed E. Abd El-Hack ${ }^{17}$ (D)

1 Agriculture Department, Faculty of Environmental Sciences, King Abdulaziz University, P.O. Box 80208, Jeddah 21589, Saudi Arabia

2 The Strategic Center to Kingdom Vision Realization, King Abdulaziz University, Jeddah, Saudi Arabia

3 Animal and Poultry Production Department, Faculty of Agriculture, Damanhour University, Damanhour, Egypt

4 Department of Agricultural Microbiology, Faculty of Agriculture, Zagazig University, Zagazig 44511, Egypt

5 Department of Animal Production, College of Food and Agriculture Sciences, King Saud University, Riyadh 11451, Saudi Arabia

6 Department of Theriogenology, Faculty of Veterinary Medicine, Zagazig University, Sharkia, Zagazig 44519, Egypt

7 Department of Biological Sciences, Microbiology, King Abdulaziz University, P.O. Box 80203, Jeddah 21589, Saudi Arabia
8 Department of Biological Sciences, Zoology, King Abdulaziz University, P.O. Box 80203, Jeddah 21589, Saudi Arabia

9 Poultry and Fish Diseases Department, Faculty of Veterinary Medicine, Damanhour University, Damanhur 22511, Egypt

10 Department of Pathology, Faculty of Veterinary Medicine, Alexandria University, Edfina, Alexandria 22758, Egypt

11 Department of Veterinary Microbiology and Immunology, College of Veterinary Sciences, Uttar Pradesh Pandit Deen Dayal Upadhyaya Pashu Chikitsa Vigyan Vishwavidyalaya Evam Go Anusandhan Sansthan (DUVASU), Mathura 281001, India

12 Division of Pathology, Indian Veterinary Research Institute (IVRI), Izatnagar-243, Bareilly, Uttar Pradesh 122, India

13 Department of Pediatric, Faculty of Medicine, King Abdualziz University, Jeddah, Saudi Arabia 
14 Department of Integrative Agriculture, College of Food and Agriculture, United Arab Emirates University, 15551 AlAin, United Arab Emirates

15 Department of Biology, College of Science, United Arab Emirates University, 15551 Al-Ain, United Arab Emirates
16

Harry Butler Institute, Murdoch University, Murdoch, Western Australia 6150, Australia

17 Department of Poultry, Faculty of Agriculture, Zagazig University, Zagazig 44511, Egypt 